\title{
Stress Prediction Model for FRP Confined Rectangular Concrete Columns with Rounded Corners
}

\author{
Thong M. Pham ${ }^{1}$ and Muhammad N.S. Hadi, M.ASCE ${ }^{2}$
}

\begin{abstract}
The paper uses the "membrane hypothesis" to formulate the confining behavior of fiber reinforced polymer (FRP) confined rectangular columns. A model was developed to calculate the strength of FRP confined rectangular concrete columns. The model was verified using a database of 190 FRP confined rectangular concrete columns. The database covers unconfined concrete strength between 18.3 $\mathrm{MPa}$ and 55.2 $\mathrm{MPa}$ and specimens with dimensions ranging from $79 \mathrm{~mm}$ to $305 \mathrm{~mm}$ and $100 \mathrm{~mm}$ to $305 \mathrm{~mm}$ for short and long sides, respectively. The performance of the proposed model shows a very good correlation with the experimental results. In addition, the strain distribution of FRP around the circumference of the rectangular sections was examined to propose an equation for predicting the actual rupture strain of FRP. The minimum corner radius of the sections is also recommended to achieve sufficient confinement.
\end{abstract}

CE Database subject headings: Fiber Reinforced Polymer; Confinement; Concrete columns; Reinforced concrete, Strain distribution.

Keywords: Rectangular columns; Square columns; Membrane hypothesis.

\footnotetext{
${ }^{1}$ Lecturer, Faculty of Civil Engineering, HCMC University of Technology, Ho Chi Minh City, Vietnam; Currently Ph.D. Candidate, School of Civil, Mining and Environmental Engineering, University of Wollongong, Wollongong, NSW 2522, Australia. Email: mtp027@uowmail.edu.au

${ }^{2}$ Associate Professor, School of Civil, Mining and Environmental Engineering, University of Wollongong, Wollongong, NSW 2522, Australia (corresponding author). Email: mhadi@uow.edu.au
} 


\section{Introduction}

Fiber Reinforced Polymers (FRP) have been commonly used to strengthen existing reinforced concrete (RC) columns. This use of FRP has been proven to increase the strength, stiffness and ductility of the strengthened columns. The use of FRP in industry has required design guidelines for these applications. Many strength models for FRP confined concrete columns, therefore, were proposed to simulate the behavior of confined concrete columns (Spoelstra and Monti 1999; Chaallal et al. 2003a; Lam and Teng 2003a; Harajli et al. 2006; Wu and Wang 2009; Cui and Sheikh 2010; Lee et al. 2010; Wu and Zhou 2010; Yazici and Hadi 2012). Most of the existing models based on Richart et al. (1928) are for circular sections causing uniform confining pressure, which can be estimated based on the strength and thickness of the FRP and the diameter of the sections.

Meanwhile, there are far fewer models for FRP confined rectangular columns as compared to circular columns (Lam and Teng 2003b; Wu and Wang 2009; Toutanji et al. 2010; Wu and Wei 2010; Wu and Zhou 2010). The confining pressure of a FRP confined rectangular column around its perimeter is not uniform. This non-uniform confining pressure leads to many difficulties to formulate the pressure distribution by a mechanical solution. Most of the existing models for rectangular sections are quite similar to circular sections except that a shape factor is introduced to account for the non-uniform confinement. In addition, the equivalent confining pressure in such cases is calculated based on mechanism analysis of circular sections. The differences between these models are the shape factor and the definition of the equivalent diameter of the rectangular sections. Therefore, analyzing the mechanism of FRP confined rectangular columns at the corners to create a model is an interesting concern of the research society. This study introduces an approach to propose a model by focusing on the stress concentration at the corners of the sections. 
This study firstly adopts the "membrane hypothesis" to analyze the behaviors of FRP at the corners of the rectangular sections. The confining pressure of the confined columns at the middle of the sides and at the corners of the sections is then examined. Next, the confining pressure at the corners of the section is estimated from the tensile properties of FRP and the corner radius. A model is proposed to estimate the strength of the confined columns, which was evaluated by a database from the literature.

\section{Confining mechanism}

\section{Confining pressure of shell structures}

FRP jacket used in confined concrete columns could be analyzed as a cylindrical shell structure subjected to hydrostatic pressure. In general the loads are carried in shell structures by a combination of "stretching" and "bending" action. But sometimes it seems clear that the bending effects are rather small when the shell structure is thin enough for eligibility of "membrane hypothesis". For such cases, the equilibrium of an infinitesimal section of the cylindrical shell structure was analyzed by Calladine (1983) as shown in Fig. 1a. The tension force of the shell structure is calculated as follows:

$$
T=r p
$$

where $T$ is the tension force in the hoop direction of the shell structure, $r$ is the radius of the infinitesimal section, and $p$ is the hydrostatic pressure applied on the structure.

This solution is also applicable for a rectangular prism with rounded corners and confined with FRP. The applicability of this solution is for thin shells which could be expected when the ratio of the round corner $(r)$ and the nominal jacket thickness $(t)$ is greater than $20(r / t>$ 20) (Calladine 1983). It is assumed that when an axial load is applied on a FRP confined rectangular concrete column, the confining pressure concentrates only at the corners of the section. The confining pressure at middle of the section sides is rather small, which could be 
negligible. For simplicity, the term "rectangular columns" in this study is used for rectangular columns with round corners.

\section{Confining pressure of FRP confined rectangular concrete columns}

When a FRP confined rectangular concrete column is subjected to an axial load, the concrete laterally expands and is confined by the FRP. The tension force of the jacket at the rupture state is calculated as follows:

$$
f_{f e}=E_{f} \varepsilon_{f e}
$$

where $f_{f e}$ is the actual tensile stress of FRP, $E_{f}$ is the elastic modulus of FRP, and $\varepsilon_{f e}$ is the actual strain of FRP at rupture.

Substituting Eq. 2 into Eq. 1, the confining pressure of the FRP confined rectangular concrete column at the corners is identical to that for a circular section, and is calculated as follows:

$$
f_{l}=\frac{n t E_{f} \varepsilon_{f e}}{r}
$$

where $f_{l}$ is the nominal confining pressure of the confined column, $t$ is the nominal thickness of FRP, $n$ is the number of FRP layers, and $r$ is the corner radius.

It is assumed that the radius of the curvature at middle of the section sides (as the column is bulging under an axial load) is much greater than that at the corners. As a result from Eq. 3, the confining pressure of the column at the middle of the sides is rather small and could be negligible. Therefore, the appropriate confining stress of a FRP confined rectangular column should be at the corners. Bakis et al. (2002) similarly concluded that the confining stress is transmitted to the concrete at the four corners of the section. The actual rupture strain of FRP at the corners of the columns should be considered and recorded, which was recommended by Wang et al. (2012) as well. Also, Csuka and Kollár (2012) analytically proved that the distribution of the confining pressure of the FRP confined square columns is concentrated at the section corners, as shown in Fig. $1 b$. 


\section{Experimental Behavior of FRP confined rectangular columns}

\section{Test database}

The number of specimens for an acceptable database was investigated before collating data of tested specimens. Table 1 summarizes the number of specimens of a few published models from the literature. Several experimental studies have been conducted on FRP confined rectangular or square concrete columns by researchers over the past few decades. This study collated a test database of 190 FRP confined rectangular concrete columns, as shown in Table 2, reported by Rochette and Labossière (2000), Shehata et al. (2002), Lam and Teng (2003b), Ilki and Kumbasar (2003), Masia et al. (2004), Harajli et al. (2006), Rousakis et al. (2007), Al-Salloum (2007), Wang and Wu (2008), Tao et al. (2008), Wu and Wei (2010), and Wang et al. (2012). The database covers unconfined concrete compressive strength between 18.3 $\mathrm{MPa}$ and 55.2 MPa. Different types of FRP were tested in the above experiments, namely carbon FRP (CFRP), aramid FRP (AFRP), and glass FRP (GFRP). The majority of specimens were plain concrete except reinforced specimens reported by Harajli et al. (2006) and Wang et al. (2012). The effect of reinforcing bars in confining the concrete was deducted when calculating the FRP confined concrete strength. The dimensions of the specimens range from $79 \mathrm{~mm}$ to $305 \mathrm{~mm}$ and $100 \mathrm{~mm}$ to $305 \mathrm{~mm}$ for shorter sides and longer sides, respectively. The aspect ratio of the specimens ranged from 1 to 2.7 , among which: 1 (138 specimens), 1.3 (16 specimens), 1.5 (12 specimens), 1.7 (12 specimens), 2 (6 specimens), and 2.7 (6 specimens).

In the above studies, reported FRP hoop strains were the average values from strain gages at the critical regions, or were taken to be the same as lateral strains deduced from measurement of linear variable differential transformers (LVDTs) at the midheight of specimens. Only the hoop strains measured by strain gages were utilized in creating a model for estimating the 
actual rupture strain of FRP. Other strains deduced from the LVDTs are average values and do not represent the hoop strains at the critical points. The FRP hoop strains of those specimens were excluded from the database while other results still were used in the verification.

For most specimens, the physical properties of FRP were determined from flat coupon tensile tests by the researchers themselves with the exception of those by Masia et al. (2004), Harajli et al. (2006), and Rousakis et al. (2007). However, the FRP properties provided by manufacturers in these studies are quite similar to the tensile properties of FRP tested by the other researchers. Those test results also fit very well with the selected models so that they were included in this database.

\section{Failure modes and distribution of FRP strain}

The specimens in Table 2 failed suddenly by tensile rupture of FRP wrap within the midheight region. The rupture position was experimentally confirmed at or near the corners of the sections (Rochette and Labossière 2000; Chaallal et al. 2003b; Wang et al. 2012; Hadi et al. 2013). Thus the mechanism of the FRP confined rectangular columns should focus on the FRP hoop strain at the corners.

It is clear that the distribution of FRP hoop strain is not uniform around the perimeter of the columns. The rupture of FRP always happens at the corner regions so that the hoop strain of FRP was expected to have the highest value at these zones. A few studies investigated the FRP hoop strain at middle of the sides and at the corners. Interestingly, the FRP hoop strain at middle of the sides is always greater than at the corners (Rochette and Labossière 2000; Smith et al. 2010; Wang et al. 2012). As a result, the mean value of all the hoop strains (including the strains at middle of the sides and at the corners) overestimates the rupture strain and the 
confinement effectiveness of FRP. In addition, the confinement is assumed to be available at the high curvature locations (e.g., corners of the sections) as presented in Eq. 1. Confinement is, therefore, only appropriate at the corners of the sections. For convenience, the phrase "rupture strain of FRP" stands for the rupture strain of FRP at the corners of the sections.

\section{Rupture strain of FRP in rectangular sections}

Wang and $\mathrm{Wu}(2008)$ conducted experiments to investigate the effect of corner radius on the rupture strain of FRP. They showed that when the radius of the corners increases, the rupture strain of FRP generally increases. An investigation was also conducted in the database reported in this study to yield the same result. It is assumed that the FRP rupture strain is dependent on the ratio of the corner radius and the side length, which could be $2 r / b$ or $2 r / h$. In addition, Wu and Wei (2010) investigated the effects of the aspect ratio $(h / b)$ on the rupture strain of FRP. They depicted that when the aspect ratio $(h / b)$ ranged from 1 to 2 , the FRP rupture strains at corners of rectangular sections were identical or close together. It means that the FRP rupture strain maintained at a certain value as tested columns had different long side length of sections but same short side length of section and material properties (unconfined concrete strength, number of FRP layers, and corners radius). In such cases, these columns had the same ratio of the corner radius and the short side length $(2 r / b)$. Therefore, this study assumed that the actual rupture strain of FRP is a function of the ratio of the corner radius and the shorter side length $(2 r / b)$.

Furthermore, an investigation was conducted on the database to show the dependence of the actual rupture strain of FRP on the confinement stiffness ratios $R_{s}$ (Rochette and Labossière 2000; Wang and Wu 2008; Wang et al. 2012). The confinement stiffness ratio $\left(R_{S}\right)$ was defined by Teng et al. (2009) as follows: 


$$
R_{s}=\frac{2 n t E_{f}}{\left(\frac{f_{c o}^{\prime}}{\varepsilon_{c o}}\right) D}
$$

where $f_{c o}{ }^{\prime}$ is the unconfined concrete strength (in $\mathrm{MPa}$ ), $\varepsilon_{c o}$ is its corresponding strain, and $D$ is the diameter of circular sections.

As this study deals with rectangular sections, the above equation was modified by replacing $D / 2$ with $r$, which is the corner radius of rectangular sections as follows:

$$
R_{s}=\frac{n t E_{f}}{\left(\frac{f_{c o}^{\prime}}{\varepsilon_{c o}}\right) r}
$$

In order to use Eq. 5, when the value of $\varepsilon_{c o}$ was not specified by the database, it was calculated as follows (Tasdemir et al. 1998):

$$
\varepsilon_{\mathrm{co}}=\left(-0.067 f_{c o}^{\prime 2}+29.9 f_{c o}^{\prime}+1053\right) 10^{-6}
$$

In conclusion, it is assumed that the actual rupture strain of FRP is a function of the ratio of the corner radius and the shorter side length $(2 r / b)$, and the confinement stiffness ratio $\left(R_{S}\right)$. Fig. 2 shows the relationship between the FRP strain efficiency factor $\left(k_{\varepsilon}\right)$, which is the ratio of the actual rupture strain of FRP and the ultimate strain of FRP from flat coupon tensile tests, and the factor $A$ defined as follows:

$$
A=\frac{2 r}{b R_{s}}
$$

where $b$ is the shorter side length of the column section. According to the linear regression analysis, the following value of the FRP strain efficiency factor $\left(k_{\varepsilon}\right)$ was obtained for FRP confined rectangular columns:

$$
k_{\varepsilon}=0.5+0.0642 \ln (A)
$$


In order to generate Eq. 8, the rupture strain of FRP at the corners of sections needs to be reported. Only a few specimens in Table 2 reported the FRP rupture strain at the corners of sections. Thus, the database used to generate Eq. 8 is smaller than the database used to verify the proposed model. Based on Fig. 2, the FRP strain efficiency factor varied between 0.4 and 0.7. It is conservatively recommended that the FRP strain efficiency factor is neither less than 0.4 nor greater than 0.7 .

\section{The proposed model}

\section{The equation for confined concrete strength}

As mentioned above, the confining pressure of a FRP confined rectangular column is not uniform around the perimeter of the sections. Thus the FRP confinement herein is only to account for confinement effect at the corners. The corner effect ratio $\left(k_{c}\right)$ introduced by Pham and Hadi (2013) was utilized to calculate the effective confining pressure $\left(f_{l, e}\right)$. The corner effect ratio is the ratio of the total length of four round corners and the circumference of the section as follows:

$$
\begin{gathered}
f_{l, e}=f_{l} k_{c} \\
k_{c}=\frac{\pi r}{b+h-r(4-\pi)}
\end{gathered}
$$

Where the nominal confining pressure $\left(f_{l}\right)$ was calculated from Eq. 3, and $b$ and $h$ are respectively the short and long sides of the column section.

The experimental stress-strain curves show two typical types including ascending and descending branches. In most cases, a FRP confined concrete column is expected to provide an ascending type curve which exhibits the well-known bilinear shape. This curve ends with the rupture of the confining jacket at the ultimate point defined by the compressive strength 
$f_{c c}$ and the ultimate axial strain $\varepsilon_{c c}$. Based on the results of the ascending type specimens in the database, the relationship between the normalized compressive strength and the normalized confining pressure is linear as shown in Fig. 3. The following equation formulates the above linear relationship as follows:

$$
\frac{f_{c c}^{\prime}}{f_{c o}^{\prime}}=0.68+3.91 \frac{f_{l, e}}{f_{c o}^{\prime}}
$$

In brief, Eq. 11 was used to calculate the compressive strength of confined concrete for specimens which have sufficient confinement. In such cases, the effective confining pressure $\left(f_{l, e}\right)$ of specimens needs to be greater than a certain value estimated from Eq. 12.

\section{The minimum amount of FRP for sufficient confinement}

A FRP confined concrete column exhibits the ascending type curve is defined as the sufficient confinement. In such a case, a significant improvement of the compressive strength and strain of a FRP confined concrete column could be expected. Otherwise, FRP confined concrete with a stress-strain curve of the descending type illustrates a concrete stress at the ultimate strain below the compressive strength of unconfined concrete. It is obvious that a confined column needs a minimum amount of FRP to obtain the sufficient confinement. Fig. 4 shows the relationship between the normalized compressive strength and the normalized effective confining pressure. From Fig. 4, in order to avoid the descending type specimens, the normalized effective confining pressure should not be less than 0.15 as follows:

$$
\frac{f_{l, e}}{f_{c o}^{\prime}} \geq 0.15
$$

Briefly, the proposed model is summarized by the following steps: (1) the FRP strain efficiency factor $\left(k_{\varepsilon}\right)$ is estimated using Eq. 8; (2) the effective confining pressure $\left(f_{l, e}\right)$ is 
calculated using Eqs. 9-10; and (3) the compressive strength of confined concrete $\left(f_{c c}\right)$ is computed as recommended in Eq. 11.

\section{Verification of the proposed model}

The model performance was tested by using three statistical indicators: the mean square error $(M S E)$, the average absolute error $(A A E)$, and the standard deviation (SD) as determined by Eqs. $13-15$.

$$
\begin{aligned}
& M S E=\frac{\sum_{1}^{N}\left(\frac{\text { pre }_{i}-\exp _{i}}{\exp _{i}}\right)^{2}}{N} \\
& A A E=\frac{\sum_{1}^{N}\left|\frac{\text { pre }_{i}-\exp _{i}}{\exp _{i}}\right|}{N} \\
& S D=\sqrt{\frac{\sum_{1}^{N}\left(\frac{\text { pre }_{i}}{\exp _{i}}-\frac{\text { pre }_{\text {avg }}}{\exp _{\text {avg }}}\right)^{2}}{N-1}}
\end{aligned}
$$

where pre is the model predictions, exp is the experimental results, the subscript "avg" means the average value, and $N$ is the total number of the test data. In general, the mean square error shows the errors to be more significant compared to the average absolute error so that it was used to emphasize the precision of the selected models.

Fig. 5 shows 104 data points (ascending type specimens) in order to assess the performance of the existing models and the proposed model. Five existing models were studied in this verification (Chaallal et al. 2003a; Lam and Teng 2003b; Wu and Wang 2009; Toutanji et al. 2010; Wu and Wei 2010). The comparison between the predictions and the test results in Fig. 5 shows the improvement of the selected models in calculating strength of FRP confined rectangular columns for a decade. Among the presented models, the proposed model has the 
highest general correlation $\left(R^{2}=89 \%\right)$ for a linear trend between the predictions and the test results. In addition, the error of the models was statistically verified and presented in Fig. 6 .

Although the establishment of the proposed model was based on the database of the ascending type specimens, the proposed model was also validated with the full database (including the descending type specimens) to verify its applicability to the descending type specimens. Fig. 7 illustrates that the proposed model predicts very well the compressive strength of FRP confined rectangular columns for both the ascending and the descending types of specimens (190 data points). The linear trend between the predictions and the test results has the general correlation factor of $0.82\left(R^{2}=82 \%\right)$, which is a small decrease compared to Fig. 5 .

As mentioned above, the behavior of the FRP jacket comply with the "membrane hypothesis" where the ratio of the round corners $(r)$ and the nominal jacket thickness $(t)$ should be greater than $20(r / t>20)$. Meanwhile, four specimens had the dimensions of $152 \times 203 \mathrm{~mm}^{2}$ and the corner radius of $5 \mathrm{~mm}$ (Rochette and Labossière 2000). These specimens were wrapped with a number of FRP layers to have a thickness of 1.2, 2.4, 3.6, and $4.8 \mathrm{~mm}$ (the $r / t$ ratios ranges between 4.2 and 1), respectively. Two specimens presented in the Al-Sallaum's study (2007) also had a corner radius of $5 \mathrm{~mm}$ (the $r / t$ ratio was 4.2 ). Therefore, the predictions of the proposed model on the strength of six specimens are not accurate $\left.\left(f_{c c(\text { pre })}\right) / f_{c c(\text { exp })}{ }^{\prime} \approx 0.75\right)$. It is recommended that FRP confined rectangular columns should be round to have a ratio of $r / t$ greater than 20).

\section{Conclusions}

A model was proposed to calculate the strength of FRP confined rectangular columns. The predictions of the proposed model fit very well with the experimental results. The study addresses the approach to analyze the mechanism of FRP confined rectangular columns, the 
actual rupture strain of FRP at corners of specimens, and the minimum amount of FRP to obtain sufficient confinement. The findings presented in this paper are summarized as follows:

1. The "membrane hypothesis" was utilized to analyze the behavior of FRP confined rectangular columns. The confining pressure of confined columns is concentrated at the corners of the section only. In order to comply with the "membrane hypothesis", the corner of the sections should be rounded to have a radius being at least twenty times greater than the nominal FRP thickness.

2. The corner effect ratio $\left(k_{c}\right)$ was accounted for the effects of the non-uniform confining pressure around rectangular sections. It was used to distribute equally the confining pressure at corners of rectangular sections to the whole circumference of the sections.

3. The actual rupture strain of FRP at corners of the sections depends on the ratio of the corner radius and the length of the shorter side, the confinement stiffness ratio as presented in Eq. 5. An equation was proposed to calculate the actual rupture strain of FRP.

4. The limit of FRP amount to obtain sufficient confinement was proposed. This limit is based not only on the ratio of the corner radius and the length of the shorter side but also the confinement stiffness ratio.

Finally, this paper used the "membrane hypothesis" to formulate the confining behaviors of FRP confined rectangular columns. This approach analyzes directly the behavior of confined square sections without conversion from equivalent circular sections to create a model for rectangular sections. The proposed model results in good correlation with experimental results.

\section{Acknowledgement}


The first author would like to acknowledge the Vietnamese Government and the University of

Wollongong for the support of his full $\mathrm{PhD}$ scholarship.

\section{Notations}

$A \quad=$ factor defined in Eq. 7;

$b \quad=$ short side of column sections;

$D \quad=$ diameter of circular sections;

$E_{f} \quad=$ elastic modulus of FRP;

$f_{f} \quad=$ tensile strength of FRP;

$f_{f e} \quad=$ actual tensile stress of FRP;

$f_{l} \quad=$ nominal confining pressure of a column;

$f_{l, e} \quad=$ effective confining pressure of a column;

$f_{c o}{ }^{\prime} \quad=$ unconfined concrete strength;

$f_{c c}{ }^{\prime}=$ confined concrete strength;

$h \quad=$ long side of column sections;

$k_{c}=$ corner effect ratio;

$k_{s} \quad=$ shape factor;

$k_{\varepsilon} \quad=$ FRP strain efficiency factor;

$n=$ number of FRP layers;

$N \quad=$ total number of the test data;

$p \quad=$ hydrostatic pressure applied in a shell structure;

$r \quad=$ corner radius of a section;

$R_{S} \quad=$ confinement stiffness ratio;

$t=$ nominal thickness of FRP;

$T \quad=$ tension force in a shell structure;

$\varepsilon_{f e}=$ actual strain of FRP at rupture;

$\varepsilon_{c c} \quad=$ ultimate axial strain of confined concrete; and

$\varepsilon_{c o}=$ axial strain of the unconfined concrete at the maximum stress.

\section{References}


Al-Salloum, Y.A. (2007). "Influence of edge sharpness on the strength of square concrete columns confined with FRP composite laminates." Composites Part B: Engineering, 38(5), 640-650.

American Concrete Institute (ACI). (2008). "Guide for the Design and Construction of Externally Bonded FRP Systems for Strengthening Concrete Structures." 440.2R-08, Farmington Hills, MI.

Bakis, C.E., Bank, L.C., Brown, V.L., Cosenza, E., Davalos, J.F., Lesko, J.J., Machida, A., Rizkalla, S.H., and Triantafillou, T.C. (2002). "Fiber-Reinforced Polymer Composites for Construction---State-of-the-Art Review." Journal of Composites for Construction, 6(2), 7387.

Calladine, C.R. (1983). Theory of shell structures. Cambridge, Cambridge University Press.

Chaallal, O., Hassan, M., and Shahawy, M. (2003a). "Confinement model for axially loaded short rectangular columns strengthened with fiber-reinforced polymer wrapping." $A C I$ Structural Journal, 100(2), 215-221.

Chaallal, O., Shahawy, M., and Hassan, M. (2003b). "Performance of axially loaded short rectangular columns strengthened with carbon fiber-reinforced polymer wrapping." Journal of Composites for Construction, 7(3), 200-208.

Csuka, B., and Kollár, L.P. (2012). "Analysis of FRP confined columns under eccentric loading." Composite Structures, 94(3), 1106-1116.

Cui, C., and Sheikh, S.A. (2010). "Analytical Model for Circular Normal- and High-Strength Concrete Columns Confined with FRP." Journal of Composites for Construction, 14(5), 562572.

Hadi, M.N.S., Pham, T.M., and Lei, X. (2013). "New Method of Strengthening Reinforced Concrete Square Columns by Circularizing and Wrapping with Fiber-Reinforced Polymer or Steel Straps." Journal of Composites for Construction, 17(2), 229-238.

Harajli, M.H., Hantouche, E., and Soudki, K. (2006). "Stress-strain model for fiber-reinforced polymer jacketed concrete columns." ACI Structural Journal, 103(5), 672-682.

Ilki, A., and Kumbasar, N. (2003). "Compressive behaviour of carbon fibre composite jacketed concrete with circular and non-circular cross-sections." Journal of earthquake Engineering, 7(3), 381-406.

Lam, L., and Teng, J.G. (2003a). "Design-oriented stress-strain model for FRP-confined concrete." Construction and Building Materials, 17(6-7), 471-489.

Lam, L., and Teng, J.G. (2003b). "Design-oriented stress-strain model for FRP-confined concrete in rectangular columns." Journal of Reinforced Plastics and Composites, 22(13), $1149-1186$.

Lee, C.-S., Hegemier, G.A., and Phillippi, D.J. (2010). "Analytical Model for FiberReinforced Polymer-Jacketed Square Concrete Columns in Axial Compression." $A C I$ Structural Journal, 107(2), 208-208-217.

Masia, M.J., Gale, T.N., and Shrive, N.G. (2004). "Size effects in axially loaded squaresection concrete prisms strengthened using carbon fibre reinforced polymer wrapping." Canadian Journal of Civil Engineering, 31(1), 1-1. 
Pham, T.M., and Hadi, M.N.S. (2013). "Strain Estimation of CFRP Confined Concrete Columns Using Energy Approach." Journal of Composites for Construction, doi: 10.1061/(ASCE)CC.1943-5614.0000397.

Richart, F.E., Brandtzaeg, A., and Brown, R.L. (1928). "A study of the failure of concrete under combined compressive stress." Bulletin 1985, Univ. of Illinois Engineering Experimental Station, Champaign, III.

Rochette, P., and Labossière, P. (2000). "Axial Testing of Rectangular Column Models Confined with Composites." Journal of Composites for Construction, 4(3), 129-136.

Rousakis, T.C., Karabinis, A.I., and Kiousis, P.D. (2007). "FRP-confined concrete members: Axial compression experiments and plasticity modelling." Engineering Structures, 29(7), $1343-1353$.

Shehata, I.A.E.M., Carneiro, L.A.V., and Shehata, L.C.D. (2002). "Strength of short concrete columns confined with CFRP sheets." Materials and Structures, 35(1), 50-58.

Smith, S.T., Kim, S.J., and Zhang, H.W. (2010). "Behavior and Effectiveness of FRP Wrap in the Confinement of Large Concrete Cylinders." Journal of Composites for Construction, 14(5), 573-582.

Spoelstra, M.R., and Monti, G. (1999). "FRP-Confined Concrete Model." Journal of Composites for Construction, 3(3), 143.

Tao, Z., Yu, Q., and Zhong, Y.Z. (2008). "Compressive behaviour of CFRP-confined rectangular concrete columns." Magazine of Concrete Research, 60(10), 735-745.

Tasdemir, M.A., Tasdemir, C., Akyüz, S., Jefferson, A.D., Lydon, F.D., and Barr, B.I.G. (1998). "Evaluation of strains at peak stresses in concrete: A three-phase composite model approach." Cement and Concrete Composites, 20(4), 301-318.

Teng, J.G., Jiang, T., Lam, L., and Luo, Y.Z. (2009). "Refinement of a Design-Oriented Stress-Strain Model for FRP-Confined Concrete." Journal of Composites for Construction, 13(4), 269-278.

Toutanji, H., Han, M., Gilbert, J., and Matthys, S. (2010). "Behavior of Large-Scale Rectangular Columns Confined with FRP Composites." Journal of Composites for Construction, 14(1), 62-71.

Wang, L.M., and Wu, Y.F. (2008). "Effect of corner radius on the performance of CFRPconfined square concrete columns: Test." Engineering Structures, 30(2), 493-505.

Wang, Z.Y., Wang, D.Y., Smith, S.T., and Lu, D.G. (2012). "CFRP-Confined Square RC Columns. I: Experimental Investigation." Journal of Composites for Construction, 16(2), 150160.

Wu, Y.F., and Wang, L.M. (2009). "Unified Strength Model for Square and Circular Concrete Columns Confined by External Jacket." Journal of Structural Engineering, 135(3), 253-261.

Wu, Y.F., and Wei, Y.Y. (2010). "Effect of cross-sectional aspect ratio on the strength of CFRP-confined rectangular concrete columns." Engineering Structures, 32(1), 32-45.

Wu, Y.F., and Zhou, Y.W. (2010). "Unified Strength Model Based on Hoek-Brown Failure Criterion for Circular and Square Concrete Columns Confined by FRP." Journal of Composites for Construction, 14(2), 175-184.

Yazici, V., and Hadi, M.N.S. (2012). "Normalized Confinement Stiffness Approach for Modeling FRP-Confined Concrete." Journal of Composites for Construction, 16(5), 520-528. 


\section{List of Figures}

Figure 1. Confinement behavior at the corner of the section: (a) mechanism of the tension force; (b) distribution of confining stress

Figure 2. Relationship between factor A and FRP strain efficiency factor $\left(k_{\varepsilon}\right)$

Figure 3. Relationship between normalized confining stress and normalized confined strength: strength equation

Figure 4. Relationship between normalized confining stress and normalized confined strength: minimum amount of FRP for sufficient confinement

Figure 5. Performance of the selected models (ascending type specimens)

Figure 6. Accuracy of the selected models

Figure 7. Performance of the proposed models (ascending and descending types specimens)

\section{List of Tables}

Table 1. Summary of published models

Table 2. Test results of FRP confined rectangular specimens 
Table 1. Summary of published models

\begin{tabular}{lcccc}
\hline Authors & Year & $\begin{array}{c}\text { Square } \\
\text { specimens }\end{array}$ & $\begin{array}{c}\text { Rectangular } \\
\text { specimens }\end{array}$ & $\begin{array}{c}\text { Total number } \\
\text { of specimens }\end{array}$ \\
\hline Challal et al. & $2003 \mathrm{a}$ & 19 & - & 19 \\
Lam and Teng & $2003 \mathrm{~b}$ & 60 & 10 & 70 \\
Al-Salloum & 2007 & 16 & - & 16 \\
Youssef et al. & 2007 & - & 38 & 38 \\
Wu and Wang & 2009 & 170 & - & 170 \\
Wu and Wei & 2010 & 22 & 60 & 82 \\
Toutanji et al. & 2010 & 59 & - & 59 \\
The proposed model & - & 138 & 52 & 190 \\
\hline
\end{tabular}


Table 2. Test results of FRP confined rectangular specimens

\begin{tabular}{|c|c|c|c|c|c|c|c|c|c|c|c|c|c|}
\hline \multirow[b]{2}{*}{ No. } & \multirow[b]{2}{*}{ Note $^{1}$} & \multicolumn{3}{|c|}{ Specimens } & \multirow{2}{*}{$\begin{array}{c}\text { Concrete } \\
f_{c o}^{\prime} \\
\mathrm{MPa}\end{array}$} & \multirow[b]{2}{*}{ Type $^{2}$} & \multirow[b]{2}{*}{$\begin{array}{l}\text { No. of } \\
\text { layers }\end{array}$} & \multicolumn{3}{|c|}{ FRP } & \multirow[b]{2}{*}{$\begin{array}{c}E_{f} \\
\mathrm{GPa}\end{array}$} & \multirow[b]{2}{*}{$\begin{array}{l}\varepsilon_{f e} \\
\%\end{array}$} & \multirow[b]{2}{*}{$\begin{array}{l}f^{\prime}{ }_{c c} \\
\mathrm{MPa}\end{array}$} \\
\hline & & $\begin{array}{c}b \\
\mathrm{~mm}\end{array}$ & $\begin{array}{c}h \\
\mathrm{~mm}\end{array}$ & $\begin{array}{c}r \\
\mathrm{~mm}\end{array}$ & & & & $\begin{array}{c}t \\
\mathrm{~mm}\end{array}$ & $\begin{array}{c}f_{f} \\
\mathrm{MPa}\end{array}$ & $\begin{array}{l}\varepsilon_{f u} \\
\%\end{array}$ & & & \\
\hline \multicolumn{14}{|c|}{ Rochette and Labossière (2000) } \\
\hline 1 & $\mathrm{~A}$ & 152 & 152 & 38 & 42.0 & $\mathrm{C}$ & 3 & 0.30 & 1265 & 1.50 & 83 & 0.71 & 47.5 \\
\hline 2 & A & 152 & 152 & 25 & 43.9 & $\mathrm{C}$ & 4 & 0.30 & 1265 & 1.50 & 83 & 0.59 & 50.9 \\
\hline 3 & $\mathrm{D}$ & 152 & 152 & 25 & 43.9 & $\mathrm{C}$ & 5 & 0.30 & 1265 & 1.50 & 83 & 0.51 & 47.9 \\
\hline 4 & A & 152 & 152 & 25 & 35.8 & $\mathrm{C}$ & 4 & 0.30 & 1265 & 1.50 & 83 & 0.70 & 52.3 \\
\hline 5 & A & 152 & 152 & 25 & 35.8 & $\mathrm{C}$ & 5 & 0.30 & 1265 & 1.50 & 83 & 0.65 & 57.6 \\
\hline 6 & A & 152 & 152 & 38 & 35.8 & $\mathrm{C}$ & 4 & 0.30 & 1265 & 1.50 & 83 & 0.89 & 59.4 \\
\hline 7 & A & 152 & 152 & 38 & 35.8 & $\mathrm{C}$ & 5 & 0.30 & 1265 & 1.50 & 83 & 0.86 & 68.7 \\
\hline 8 & $\mathrm{D}$ & 152 & 203 & 5 & 43.0 & A & 3 & 0.42 & 230 & 1.69 & 14 & 0.79 & 50.7 \\
\hline 9 & $\mathrm{D}$ & 152 & 203 & 5 & 43.0 & A & 6 & 0.42 & 230 & 1.69 & 14 & 1.30 & 51.6 \\
\hline 10 & $\mathrm{D}$ & 152 & 203 & 5 & 43.0 & A & 9 & 0.42 & 230 & 1.69 & 14 & 1.48 & 53.8 \\
\hline 11 & $\mathrm{D}$ & 152 & 203 & 5 & 43.0 & A & 12 & 0.42 & 230 & 1.69 & 14 & 0.90 & 54.2 \\
\hline 12 & $\mathrm{D}$ & 152 & 203 & 25 & 43.0 & A & 3 & 0.42 & 230 & 1.69 & 14 & 1.12 & 51.2 \\
\hline 13 & $\mathrm{D}$ & 152 & 203 & 25 & 43.0 & A & 6 & 0.42 & 230 & 1.69 & 14 & 1.27 & 51.2 \\
\hline 14 & $\mathrm{D}$ & 152 & 203 & 25 & 43.0 & A & 9 & 0.42 & 230 & 1.69 & 14 & 0.94 & 53.3 \\
\hline 15 & A & 152 & 203 & 25 & 43.0 & A & 12 & 0.42 & 230 & 1.69 & 14 & 1.04 & 55.0 \\
\hline 16 & $\mathrm{D}$ & 152 & 203 & 38 & 43.0 & A & 6 & 0.42 & 230 & 1.69 & 14 & 1.05 & 50.7 \\
\hline 17 & A & 152 & 203 & 38 & 43.0 & A & 9 & 0.42 & 230 & 1.69 & 14 & 0.97 & 52.9 \\
\hline \multicolumn{14}{|c|}{ Harajli et al. (2006) } \\
\hline 18 & $\mathrm{~A}$ & 132 & 132 & 15 & 18.3 & $\mathrm{C}$ & 1 & 0.13 & 3500 & 1.50 & 230 & - & 28.9 \\
\hline 19 & $\mathrm{~A}$ & 132 & 132 & 15 & 18.3 & $\mathrm{C}$ & 2 & 0.13 & 3500 & 1.50 & 230 & - & 40.0 \\
\hline 20 & A & 132 & 132 & 15 & 18.3 & $\mathrm{C}$ & 3 & 0.13 & 3500 & 1.50 & 230 & - & 43.1 \\
\hline 21 & $\mathrm{~A}$ & 132 & 132 & 15 & 18.3 & $\mathrm{C}$ & 1 & 0.13 & 3500 & 1.50 & 230 & - & 25.4 \\
\hline 22 & $\mathrm{~A}$ & 132 & 132 & 15 & 18.3 & $\mathrm{C}$ & 2 & 0.13 & 3500 & 1.50 & 230 & - & 36.8 \\
\hline 23 & A & 132 & 132 & 15 & 18.3 & $\mathrm{C}$ & 3 & 0.13 & 3500 & 1.50 & 230 & - & 47.0 \\
\hline 24 & A & 102 & 176 & 15 & 18.3 & $\mathrm{C}$ & 1 & 0.13 & 3500 & 1.50 & 230 & - & 23.5 \\
\hline 25 & A & 102 & 176 & 15 & 18.3 & $\mathrm{C}$ & 2 & 0.13 & 3500 & 1.50 & 230 & - & 31.0 \\
\hline 26 & A & 102 & 176 & 15 & 18.3 & $\mathrm{C}$ & 3 & 0.13 & 3500 & 1.50 & 230 & - & 36.5 \\
\hline 27 & A & 102 & 176 & 15 & 18.3 & $\mathrm{C}$ & 1 & 0.13 & 3500 & 1.50 & 230 & - & 21.5 \\
\hline 28 & A & 102 & 176 & 15 & 18.3 & $\mathrm{C}$ & 2 & 0.13 & 3500 & 1.50 & 230 & - & 27.8 \\
\hline 29 & A & 102 & 176 & 15 & 18.3 & $\mathrm{C}$ & 3 & 0.13 & 3500 & 1.50 & 230 & - & 36.4 \\
\hline 30 & $\mathrm{D}$ & 79 & 214 & 15 & 18.3 & $\mathrm{C}$ & 1 & 0.13 & 3500 & 1.50 & 230 & - & 27.8 \\
\hline 31 & $\mathrm{D}$ & 79 & 214 & 15 & 18.3 & $\mathrm{C}$ & 2 & 0.13 & 3500 & 1.50 & 230 & - & 28.4 \\
\hline 32 & $\mathrm{D}$ & 79 & 214 & 15 & 18.3 & $\mathrm{C}$ & 3 & 0.13 & 3500 & 1.50 & 230 & - & 30.4 \\
\hline 33 & $\mathrm{D}$ & 79 & 214 & 15 & 18.3 & $\mathrm{C}$ & 1 & 0.13 & 3500 & 1.50 & 230 & - & 18.5 \\
\hline 34 & A & 79 & 214 & 15 & 18.3 & $\mathrm{C}$ & 2 & 0.13 & 3500 & 1.50 & 230 & - & 22.0 \\
\hline 35 & A & 79 & 214 & 15 & 18.3 & $\mathrm{C}$ & 3 & 0.13 & 3500 & 1.50 & 230 & - & 28.9 \\
\hline
\end{tabular}


Table 2. Test results of FRP confined rectangular specimens (Cont.)

\begin{tabular}{|c|c|c|c|c|c|c|c|c|c|c|c|c|c|}
\hline \multirow[b]{2}{*}{ No. } & \multirow[b]{2}{*}{ Note $^{1}$} & \multicolumn{3}{|c|}{ Specimens } & \multicolumn{3}{|c|}{ Concrete } & \multicolumn{3}{|c|}{ FRP } & \multirow[b]{2}{*}{$\begin{array}{c}E_{f} \\
\mathrm{GPa}\end{array}$} & \multirow[b]{2}{*}{$\begin{array}{l}\varepsilon_{f e} \\
\%\end{array}$} & \multirow[b]{2}{*}{$\begin{array}{l}f^{\prime}{ }_{c c} \\
\mathrm{MPa}\end{array}$} \\
\hline & & $\begin{array}{c}b \\
\mathrm{~mm}\end{array}$ & $\begin{array}{c}h \\
\mathrm{~mm}\end{array}$ & $\begin{array}{c}r \\
\mathrm{~mm}\end{array}$ & $\begin{array}{l}f_{c o}^{\prime} \\
\mathrm{MPa}\end{array}$ & Type $^{2}$ & $\begin{array}{l}\text { No. of } \\
\text { layers }\end{array}$ & $\begin{array}{c}t \\
\mathrm{~mm}\end{array}$ & $\begin{array}{c}f_{f} \\
\mathrm{MPa}\end{array}$ & $\begin{array}{l}\varepsilon_{f u} \\
\%\end{array}$ & & & \\
\hline \multicolumn{14}{|c|}{ Rousakis et al. (2007) } \\
\hline 36 & $\mathrm{D}$ & 200 & 200 & 30 & 33.0 & $\mathrm{C}$ & 1 & 0.12 & 3720 & 1.55 & 240 & - & 38.4 \\
\hline 37 & $\mathrm{~A}$ & 200 & 200 & 30 & 33.0 & $\mathrm{C}$ & 3 & 0.12 & 3720 & 1.55 & 240 & - & 45.9 \\
\hline 38 & $\mathrm{~A}$ & 200 & 200 & 30 & 33.0 & $\mathrm{C}$ & 5 & 0.12 & 3720 & 1.55 & 240 & - & 55.6 \\
\hline 39 & $\mathrm{D}$ & 200 & 200 & 30 & 33.0 & $\mathrm{G}$ & 3 & 0.14 & 1820 & 2.80 & 65 & - & 42.6 \\
\hline 40 & $\mathrm{~A}$ & 200 & 200 & 30 & 33.0 & $\mathrm{G}$ & 6 & 0.14 & 1820 & 2.80 & 65 & - & 44.4 \\
\hline 41 & A & 200 & 200 & 30 & 33.0 & $\mathrm{G}$ & 9 & 0.14 & 1820 & 2.80 & 65 & - & 51.9 \\
\hline 42 & $\mathrm{D}$ & 200 & 200 & 30 & 34.0 & $\mathrm{C}$ & 1 & 0.12 & 3720 & 1.55 & 240 & - & 42.2 \\
\hline 43 & $\mathrm{D}$ & 200 & 200 & 30 & 34.0 & $\mathrm{C}$ & 3 & 0.12 & 3720 & 1.55 & 240 & - & 45.2 \\
\hline 44 & A & 200 & 200 & 30 & 34.0 & $\mathrm{C}$ & 5 & 0.12 & 3720 & 1.55 & 240 & - & 54.6 \\
\hline 45 & $\mathrm{D}$ & 200 & 200 & 30 & 38.0 & $\mathrm{G}$ & 6 & 0.14 & 1820 & 2.80 & 65 & - & 52.8 \\
\hline 46 & $\mathrm{D}$ & 200 & 200 & 30 & 38.0 & $\mathrm{G}$ & 9 & 0.14 & 1820 & 2.80 & 65 & - & 59.8 \\
\hline 47 & $\mathrm{D}$ & 200 & 200 & 30 & 40.0 & $\mathrm{G}$ & 6 & 0.14 & 1820 & 2.80 & 65 & - & 54.2 \\
\hline 48 & $\mathrm{D}$ & 200 & 200 & 30 & 40.0 & $\mathrm{G}$ & 9 & 0.14 & 1820 & 2.80 & 65 & - & 59.5 \\
\hline \multicolumn{14}{|c|}{ Lam and Teng (2003b) } \\
\hline 49 & $\mathrm{D}$ & 150 & 150 & 15 & 33.7 & $\mathrm{C}$ & 1 & 0.17 & 4519 & 1.76 & 257 & - & 35.0 \\
\hline 50 & $\mathrm{~A}$ & 150 & 150 & 25 & 33.7 & $\mathrm{C}$ & 1 & 0.17 & 4519 & 1.76 & 257 & - & 39.4 \\
\hline 51 & A & 150 & 150 & 15 & 33.7 & $\mathrm{C}$ & 2 & 0.17 & 4519 & 1.76 & 257 & - & 50.4 \\
\hline 52 & $\mathrm{~A}$ & 150 & 150 & 25 & 33.7 & $\mathrm{C}$ & 2 & 0.17 & 4519 & 1.76 & 257 & - & 61.9 \\
\hline 53 & A & 150 & 150 & 15 & 24.0 & $\mathrm{C}$ & 3 & 0.17 & 4519 & 1.76 & 257 & - & 61.6 \\
\hline 54 & A & 150 & 150 & 25 & 24.0 & $\mathrm{C}$ & 3 & 0.17 & 4519 & 1.76 & 257 & - & 66.0 \\
\hline \multicolumn{14}{|c|}{ Masia et al. (2004) } \\
\hline 55 & $\mathrm{~A}$ & 100 & 100 & 25 & 25.5 & $\mathrm{C}$ & 2 & 0.13 & 3500 & 1.50 & 230 & - & 55.9 \\
\hline 56 & A & 100 & 100 & 25 & 22.8 & $\mathrm{C}$ & 2 & 0.13 & 3500 & 1.50 & 230 & - & 48.7 \\
\hline 57 & A & 100 & 100 & 25 & 25.1 & $\mathrm{C}$ & 2 & 0.13 & 3500 & 1.50 & 230 & - & 45.7 \\
\hline 58 & $\mathrm{~A}$ & 100 & 100 & 25 & 23.8 & $\mathrm{C}$ & 2 & 0.13 & 3500 & 1.50 & 230 & - & 50.7 \\
\hline 59 & A & 100 & 100 & 25 & 21.7 & $\mathrm{C}$ & 2 & 0.13 & 3500 & 1.50 & 230 & - & 56.2 \\
\hline 60 & A & 125 & 125 & 25 & 23.7 & $\mathrm{C}$ & 2 & 0.13 & 3500 & 1.50 & 230 & - & 45.0 \\
\hline 61 & A & 125 & 125 & 25 & 22.9 & $\mathrm{C}$ & 2 & 0.13 & 3500 & 1.50 & 230 & - & 39.9 \\
\hline 62 & A & 125 & 125 & 25 & 25.7 & $\mathrm{C}$ & 2 & 0.13 & 3500 & 1.50 & 230 & - & 42.1 \\
\hline 63 & A & 125 & 125 & 25 & 25.5 & $\mathrm{C}$ & 2 & 0.13 & 3500 & 1.50 & 230 & - & 35.5 \\
\hline 64 & A & 125 & 125 & 25 & 24.3 & $\mathrm{C}$ & 2 & 0.13 & 3500 & 1.50 & 230 & - & 40.2 \\
\hline 65 & A & 150 & 150 & 25 & 24.5 & $\mathrm{C}$ & 2 & 0.13 & 3500 & 1.50 & 230 & - & 35.7 \\
\hline 66 & A & 150 & 150 & 25 & 21.3 & $\mathrm{C}$ & 2 & 0.13 & 3500 & 1.50 & 230 & - & 36.2 \\
\hline 67 & A & 150 & 150 & 25 & 24.8 & $\mathrm{C}$ & 2 & 0.13 & 3500 & 1.50 & 230 & - & 36.6 \\
\hline 68 & A & 150 & 150 & 25 & 23.6 & $\mathrm{C}$ & 2 & 0.13 & 3500 & 1.50 & 230 & - & 36.5 \\
\hline 69 & A & 150 & 150 & 25 & 25.3 & $\mathrm{C}$ & 2 & 0.13 & 3500 & 1.50 & 230 & - & 36.0 \\
\hline
\end{tabular}


Table 2. Test results of FRP confined rectangular specimens (Cont.)

\begin{tabular}{|c|c|c|c|c|c|c|c|c|c|c|c|c|c|}
\hline \multirow[b]{2}{*}{ No. } & \multirow[b]{2}{*}{ Note $^{1}$} & \multicolumn{3}{|c|}{ Specimens } & \multirow{2}{*}{$\begin{array}{c}\text { Concrete } \\
f_{c o}^{\prime} \\
\mathrm{MPa}\end{array}$} & \multicolumn{8}{|c|}{ FRP } \\
\hline & & $\begin{array}{c}b \\
\mathrm{~mm} \\
\end{array}$ & $\begin{array}{c}h \\
\mathrm{~mm} \\
\end{array}$ & $\begin{array}{c}r \\
\mathrm{~mm} \\
\end{array}$ & & Type $^{2}$ & $\begin{array}{l}\text { No. of } \\
\text { layers }\end{array}$ & $\begin{array}{c}t \\
\mathrm{~mm}\end{array}$ & $\begin{array}{c}f_{f} \\
\mathrm{MPa}\end{array}$ & $\begin{array}{l}\varepsilon_{f u} \\
\%\end{array}$ & $\begin{array}{c}E_{f} \\
\mathrm{GPa}\end{array}$ & $\begin{array}{l}\varepsilon_{f e} \\
\%\end{array}$ & $\begin{array}{l}f^{\prime} c c \\
\mathrm{MPa}\end{array}$ \\
\hline \multicolumn{14}{|c|}{ Wang and $\mathrm{Wu}(2008)$} \\
\hline 70 & $\mathrm{D}$ & 150 & 150 & 15 & 32.9 & $\mathrm{C}$ & 1 & 0.17 & 4364 & 1.99 & 219 & 1.39 & 38.8 \\
\hline 71 & $\mathrm{D}$ & 150 & 150 & 15 & 32.2 & $\mathrm{C}$ & 1 & 0.17 & 4364 & 1.99 & 219 & 1.39 & 31.0 \\
\hline 72 & $\mathrm{D}$ & 150 & 150 & 15 & 30.7 & $\mathrm{C}$ & 1 & 0.17 & 4364 & 1.99 & 219 & 1.39 & 30.8 \\
\hline 73 & $\mathrm{~A}$ & 150 & 150 & 15 & 32.9 & $\mathrm{C}$ & 2 & 0.17 & 4364 & 1.99 & 219 & 1.16 & 40.5 \\
\hline 74 & A & 150 & 150 & 15 & 32.2 & $\mathrm{C}$ & 2 & 0.17 & 4364 & 1.99 & 219 & 1.16 & 43.6 \\
\hline 75 & $\mathrm{~A}$ & 150 & 150 & 15 & 30.7 & $\mathrm{C}$ & 2 & 0.17 & 4364 & 1.99 & 219 & 1.16 & 42.4 \\
\hline 76 & A & 150 & 150 & 30 & 32.6 & $\mathrm{C}$ & 1 & 0.17 & 4364 & 1.99 & 219 & 1.11 & 43.4 \\
\hline 77 & $\mathrm{~A}$ & 150 & 150 & 30 & 31.1 & $\mathrm{C}$ & 1 & 0.17 & 4364 & 1.99 & 219 & 1.11 & 38.8 \\
\hline 78 & A & 150 & 150 & 30 & 33.1 & $\mathrm{C}$ & 1 & 0.17 & 4364 & 1.99 & 219 & 1.11 & 37.1 \\
\hline 79 & A & 150 & 150 & 30 & 32.6 & $\mathrm{C}$ & 2 & 0.17 & 4364 & 1.99 & 219 & 1.28 & 58.1 \\
\hline 80 & A & 150 & 150 & 30 & 31.1 & $\mathrm{C}$ & 2 & 0.17 & 4364 & 1.99 & 219 & 1.28 & 57.5 \\
\hline 81 & A & 150 & 150 & 30 & 33.1 & $\mathrm{C}$ & 2 & 0.17 & 4364 & 1.99 & 219 & 1.28 & 53.8 \\
\hline 82 & $\mathrm{~A}$ & 150 & 150 & 45 & 30.1 & $\mathrm{C}$ & 1 & 0.17 & 4364 & 1.99 & 219 & 1.27 & 48.3 \\
\hline 83 & A & 150 & 150 & 45 & 32.6 & $\mathrm{C}$ & 1 & 0.17 & 4364 & 1.99 & 219 & 1.27 & 42.1 \\
\hline 84 & $\mathrm{~A}$ & 150 & 150 & 45 & 29.3 & $\mathrm{C}$ & 1 & 0.17 & 4364 & 1.99 & 219 & 1.27 & 40.8 \\
\hline 85 & A & 150 & 150 & 45 & 30.1 & $\mathrm{C}$ & 2 & 0.17 & 4364 & 1.99 & 219 & 1.68 & 64.6 \\
\hline 86 & $\mathrm{~A}$ & 150 & 150 & 45 & 32.6 & $\mathrm{C}$ & 2 & 0.17 & 4364 & 1.99 & 219 & 1.68 & 69.4 \\
\hline 87 & A & 150 & 150 & 45 & 29.3 & $\mathrm{C}$ & 2 & 0.17 & 4364 & 1.99 & 219 & 1.68 & 70.1 \\
\hline 88 & $\mathrm{~A}$ & 150 & 150 & 60 & 30.9 & $\mathrm{C}$ & 1 & 0.17 & 4364 & 1.99 & 219 & 1.37 & 50.9 \\
\hline 89 & $\mathrm{~A}$ & 150 & 150 & 60 & 31.1 & $\mathrm{C}$ & 1 & 0.17 & 4364 & 1.99 & 219 & 1.37 & 51.7 \\
\hline 90 & $\mathrm{~A}$ & 150 & 150 & 60 & 33.5 & $\mathrm{C}$ & 1 & 0.17 & 4364 & 1.99 & 219 & 1.37 & 47.3 \\
\hline 91 & $\mathrm{~A}$ & 150 & 150 & 60 & 30.9 & $\mathrm{C}$ & 2 & 0.17 & 4364 & 1.99 & 219 & 1.75 & 81.1 \\
\hline 92 & $\mathrm{~A}$ & 150 & 150 & 60 & 31.1 & $\mathrm{C}$ & 2 & 0.17 & 4364 & 1.99 & 219 & 1.75 & 73.6 \\
\hline 93 & $\mathrm{~A}$ & 150 & 150 & 60 & 33.5 & $\mathrm{C}$ & 2 & 0.17 & 4364 & 1.99 & 219 & 1.75 & 82.1 \\
\hline 94 & $\mathrm{D}$ & 150 & 150 & 15 & 54.7 & $\mathrm{C}$ & 1 & 0.17 & 3788 & 1.92 & 226 & 1.01 & 55.0 \\
\hline 95 & $\mathrm{D}$ & 150 & 150 & 15 & 55.2 & $\mathrm{C}$ & 1 & 0.17 & 3788 & 1.92 & 226 & 1.01 & 56.1 \\
\hline 96 & $\mathrm{D}$ & 150 & 150 & 15 & 52.5 & $\mathrm{C}$ & 1 & 0.17 & 3788 & 1.92 & 226 & 1.01 & 56.2 \\
\hline 97 & $\mathrm{D}$ & 150 & 150 & 15 & 54.7 & $\mathrm{C}$ & 2 & 0.17 & 3788 & 1.92 & 226 & 0.62 & 59.6 \\
\hline 98 & $\mathrm{D}$ & 150 & 150 & 15 & 55.2 & $\mathrm{C}$ & 2 & 0.17 & 3788 & 1.92 & 226 & 0.62 & 59.6 \\
\hline 99 & $\mathrm{D}$ & 150 & 150 & 15 & 52.5 & $\mathrm{C}$ & 2 & 0.17 & 3788 & 1.92 & 226 & 0.62 & 59.0 \\
\hline 100 & $\mathrm{D}$ & 150 & 150 & 30 & 53.5 & $\mathrm{C}$ & 1 & 0.17 & 3788 & 1.92 & 226 & 1.10 & 56.2 \\
\hline 101 & $\mathrm{D}$ & 150 & 150 & 30 & 53.1 & $\mathrm{C}$ & 1 & 0.17 & 3788 & 1.92 & 226 & 1.10 & 55.5 \\
\hline 102 & $\mathrm{D}$ & 150 & 150 & 30 & 49.4 & $\mathrm{C}$ & 1 & 0.17 & 3788 & 1.92 & 226 & 1.10 & 56.0 \\
\hline 103 & $\mathrm{D}$ & 150 & 150 & 30 & 53.5 & $\mathrm{C}$ & 2 & 0.17 & 3788 & 1.92 & 226 & 1.17 & 65.2 \\
\hline 104 & $\mathrm{D}$ & 150 & 150 & 30 & 53.1 & $\mathrm{C}$ & 2 & 0.17 & 3788 & 1.92 & 226 & 1.17 & 61.4 \\
\hline 105 & $\mathrm{D}$ & 150 & 150 & 30 & 49.4 & $\mathrm{C}$ & 2 & 0.17 & 3788 & 1.92 & 226 & 1.17 & 62.5 \\
\hline 106 & $\mathrm{D}$ & 150 & 150 & 45 & 53.2 & $\mathrm{C}$ & 1 & 0.17 & 3788 & 1.92 & 226 & 1.34 & 56.4 \\
\hline 107 & $\mathrm{D}$ & 150 & 150 & 45 & 51.5 & $\mathrm{C}$ & 1 & 0.17 & 3788 & 1.92 & 226 & 1.34 & 58.4 \\
\hline 108 & $\mathrm{D}$ & 150 & 150 & 45 & 53.3 & $\mathrm{C}$ & 1 & 0.17 & 3788 & 1.92 & 226 & 1.34 & 57.9 \\
\hline
\end{tabular}


Table 2. Test results of FRP confined rectangular specimens (Cont.)

\begin{tabular}{|c|c|c|c|c|c|c|c|c|c|c|c|c|c|}
\hline \multirow[b]{2}{*}{ No. } & \multirow[b]{2}{*}{ Note $^{1}$} & \multicolumn{3}{|c|}{ Specimens } & \multirow{2}{*}{$\begin{array}{c}\text { Concrete } \\
f_{c o}^{\prime} \\
\mathrm{MPa}\end{array}$} & \multirow[b]{2}{*}{ Type $^{2}$} & \multicolumn{4}{|c|}{ FRP } & \multirow[b]{2}{*}{$\begin{array}{c}E_{f} \\
\mathrm{GPa}\end{array}$} & \multirow[b]{2}{*}{$\begin{array}{l}\varepsilon_{f e} \\
\%\end{array}$} & \multirow[b]{2}{*}{$\begin{array}{l}f^{\prime} c c \\
\mathrm{MPa}\end{array}$} \\
\hline & & $\begin{array}{c}b \\
\mathrm{~mm} \\
\end{array}$ & $\begin{array}{c}h \\
\mathrm{~mm} \\
\end{array}$ & $\begin{array}{c}r \\
\mathrm{~mm} \\
\end{array}$ & & & $\begin{array}{l}\text { No. of } \\
\text { layers }\end{array}$ & $\begin{array}{c}t \\
\mathrm{~mm} \\
\end{array}$ & $\begin{array}{c}f_{f} \\
\mathrm{MPa} \\
\end{array}$ & $\begin{array}{l}\varepsilon_{f u} \\
\%\end{array}$ & & & \\
\hline \multicolumn{14}{|c|}{ Wang and $\mathrm{Wu}(2008)$} \\
\hline 109 & $\mathrm{~A}$ & 150 & 150 & 45 & 53.2 & $\mathrm{C}$ & 2 & 0.17 & 3788 & 1.92 & 226 & 1.27 & 81.3 \\
\hline 110 & $\mathrm{~A}$ & 150 & 150 & 45 & 51.5 & $\mathrm{C}$ & 2 & 0.17 & 3788 & 1.92 & 226 & 1.27 & 78.8 \\
\hline 111 & $\mathrm{~A}$ & 150 & 150 & 45 & 53.3 & $\mathrm{C}$ & 2 & 0.17 & 3788 & 1.92 & 226 & 1.27 & 80.9 \\
\hline 112 & $\mathrm{~A}$ & 150 & 150 & 60 & 53.9 & $\mathrm{C}$ & 1 & 0.17 & 3788 & 1.92 & 226 & 1.39 & 62.4 \\
\hline 113 & A & 150 & 150 & 60 & 52.0 & $\mathrm{C}$ & 1 & 0.17 & 3788 & 1.92 & 226 & 1.39 & 62.7 \\
\hline 114 & $\mathrm{~A}$ & 150 & 150 & 60 & 52.3 & $\mathrm{C}$ & 1 & 0.17 & 3788 & 1.92 & 226 & 1.39 & 62.8 \\
\hline 115 & A & 150 & 150 & 60 & 53.9 & $\mathrm{C}$ & 2 & 0.17 & 3788 & 1.92 & 226 & 1.38 & 87.9 \\
\hline 116 & $\mathrm{~A}$ & 150 & 150 & 60 & 52.0 & $\mathrm{C}$ & 2 & 0.17 & 3788 & 1.92 & 226 & 1.38 & 90.9 \\
\hline 117 & A & 150 & 150 & 60 & 52.3 & $\mathrm{C}$ & 2 & 0.17 & 3788 & 1.92 & 226 & 1.38 & 90.4 \\
\hline \multicolumn{14}{|c|}{$\mathrm{Wu}$ and Wei (2010) } \\
\hline 118 & $\mathrm{~A}$ & 150 & 150 & 30 & 35.3 & $\mathrm{C}$ & 1 & 0.17 & 4192 & 1.84 & 229 & 1.84 & 40.5 \\
\hline 119 & $\mathrm{~A}$ & 150 & 150 & 30 & 35.3 & $\mathrm{C}$ & 1 & 0.17 & 4192 & 1.84 & 229 & 1.84 & 40.7 \\
\hline 120 & $\mathrm{~A}$ & 150 & 150 & 30 & 35.3 & $\mathrm{C}$ & 1 & 0.17 & 4192 & 1.84 & 229 & 1.84 & 42.5 \\
\hline 121 & $\mathrm{~A}$ & 150 & 150 & 30 & 35.3 & $\mathrm{C}$ & 2 & 0.17 & 4192 & 1.84 & 229 & 1.21 & 59.2 \\
\hline 122 & $\mathrm{~A}$ & 150 & 150 & 30 & 35.3 & $\mathrm{C}$ & 2 & 0.17 & 4192 & 1.84 & 229 & 1.21 & 59.6 \\
\hline 123 & $\mathrm{~A}$ & 150 & 150 & 30 & 35.3 & $\mathrm{C}$ & 2 & 0.17 & 4192 & 1.84 & 229 & 1.21 & 62.3 \\
\hline 124 & $\mathrm{D}$ & 150 & 188 & 30 & 35.3 & $\mathrm{C}$ & 1 & 0.17 & 4192 & 1.84 & 229 & 1.46 & 38.0 \\
\hline 125 & $\mathrm{D}$ & 150 & 188 & 30 & 35.3 & $\mathrm{C}$ & 1 & 0.17 & 4192 & 1.84 & 229 & 1.46 & 38.9 \\
\hline 126 & D & 150 & 188 & 30 & 35.3 & $\mathrm{C}$ & 1 & 0.17 & 4192 & 1.84 & 229 & 1.46 & 39.4 \\
\hline 127 & $\mathrm{~A}$ & 150 & 188 & 30 & 35.3 & $\mathrm{C}$ & 2 & 0.17 & 4192 & 1.84 & 229 & 1.33 & 48.8 \\
\hline 128 & $\mathrm{~A}$ & 150 & 188 & 30 & 35.3 & $\mathrm{C}$ & 2 & 0.17 & 4192 & 1.84 & 229 & 1.33 & 51.9 \\
\hline 129 & A & 150 & 188 & 30 & 35.3 & $\mathrm{C}$ & 2 & 0.17 & 4192 & 1.84 & 229 & 1.33 & 53.3 \\
\hline 130 & $\mathrm{D}$ & 150 & 225 & 30 & 35.3 & $\mathrm{C}$ & 1 & 0.17 & 4192 & 1.84 & 229 & 1.58 & 37.6 \\
\hline 131 & $\mathrm{D}$ & 150 & 225 & 30 & 35.3 & $\mathrm{C}$ & 1 & 0.17 & 4192 & 1.84 & 229 & 1.58 & 35.6 \\
\hline 132 & $\mathrm{D}$ & 150 & 225 & 30 & 35.3 & $\mathrm{C}$ & 1 & 0.17 & 4192 & 1.84 & 229 & 1.58 & 39.2 \\
\hline 133 & $\mathrm{~A}$ & 150 & 225 & 30 & 35.3 & $\mathrm{C}$ & 2 & 0.17 & 4192 & 1.84 & 229 & 1.44 & 43.0 \\
\hline 134 & $\mathrm{~A}$ & 150 & 225 & 30 & 35.3 & $\mathrm{C}$ & 2 & 0.17 & 4192 & 1.84 & 229 & 1.44 & 45.2 \\
\hline 135 & $\mathrm{~A}$ & 150 & 225 & 30 & 35.3 & $\mathrm{C}$ & 2 & 0.17 & 4192 & 1.84 & 229 & 1.44 & 43.4 \\
\hline 136 & $\mathrm{D}$ & 150 & 260 & 30 & 35.3 & $\mathrm{C}$ & 1 & 0.17 & 4192 & 1.84 & 229 & 1.31 & 35.2 \\
\hline 137 & $\mathrm{D}$ & 150 & 260 & 30 & 35.3 & $\mathrm{C}$ & 1 & 0.17 & 4192 & 1.84 & 229 & 1.31 & 37.8 \\
\hline 138 & $\mathrm{D}$ & 150 & 260 & 30 & 35.3 & $\mathrm{C}$ & 1 & 0.17 & 4192 & 1.84 & 229 & 1.31 & 37.6 \\
\hline 139 & $\mathrm{D}$ & 150 & 260 & 30 & 35.3 & $\mathrm{C}$ & 2 & 0.17 & 4192 & 1.84 & 229 & 1.72 & 38.9 \\
\hline 140 & $\mathrm{D}$ & 150 & 260 & 30 & 35.3 & $\mathrm{C}$ & 2 & 0.17 & 4192 & 1.84 & 229 & 1.72 & 41.4 \\
\hline 141 & D & 150 & 260 & 30 & 35.3 & $\mathrm{C}$ & 2 & 0.17 & 4192 & 1.84 & 229 & 1.72 & 41.3 \\
\hline 142 & $\mathrm{D}$ & 150 & 300 & 30 & 35.3 & $\mathrm{C}$ & 1 & 0.17 & 4192 & 1.84 & 229 & 1.15 & 36.6 \\
\hline 143 & $\mathrm{D}$ & 150 & 300 & 30 & 35.3 & $\mathrm{C}$ & 1 & 0.17 & 4192 & 1.84 & 229 & 1.15 & 37.7 \\
\hline 144 & $\mathrm{D}$ & 150 & 300 & 30 & 35.3 & $\mathrm{C}$ & 1 & 0.17 & 4192 & 1.84 & 229 & 1.15 & 38.0 \\
\hline 145 & $\mathrm{D}$ & 150 & 300 & 30 & 35.3 & $\mathrm{C}$ & 2 & 0.17 & 4192 & 1.84 & 229 & 1.37 & 38.6 \\
\hline
\end{tabular}


Table 2. Test results of FRP confined rectangular specimens (Cont.)

\begin{tabular}{|c|c|c|c|c|c|c|c|c|c|c|c|c|c|}
\hline \multirow[b]{2}{*}{ No. } & \multirow[b]{2}{*}{ Note $^{1}$} & \multicolumn{3}{|c|}{ Specimens } & \multirow{2}{*}{$\begin{array}{c}\text { Concrete } \\
f^{\prime}{ }_{c o} \\
\mathrm{MPa}\end{array}$} & \multicolumn{8}{|c|}{ FRP } \\
\hline & & $\begin{array}{c}b \\
\mathrm{~mm} \\
\end{array}$ & $\begin{array}{c}h \\
\mathrm{~mm}\end{array}$ & $\begin{array}{c}r \\
\mathrm{~mm} \\
\end{array}$ & & Type $^{2}$ & $\begin{array}{l}\text { No. of } \\
\text { layers }\end{array}$ & $\begin{array}{c}t \\
\mathrm{~mm}\end{array}$ & $\begin{array}{c}f_{f} \\
\mathrm{MPa}\end{array}$ & $\begin{array}{l}\varepsilon_{f u} \\
\%\end{array}$ & $\begin{array}{c}E_{f} \\
\mathrm{GPa}\end{array}$ & $\begin{array}{l}\mathcal{E}_{f e} \\
\%\end{array}$ & $\begin{array}{c}f^{\prime} c c \\
\mathrm{MPa}\end{array}$ \\
\hline \multicolumn{14}{|c|}{ Wu and Wei (2010) } \\
\hline 146 & $\mathrm{D}$ & 150 & 300 & 30 & 35.3 & $\mathrm{C}$ & 2 & 0.17 & 4192 & 1.84 & 229 & 1.37 & 39.1 \\
\hline 147 & $\mathrm{D}$ & 150 & 300 & 30 & 35.3 & $\mathrm{C}$ & 2 & 0.17 & 4192 & 1.84 & 229 & 1.37 & 39.3 \\
\hline \multicolumn{14}{|c|}{ Wang et al. (2012) } \\
\hline 148 & $\mathrm{D}$ & 305 & 305 & 30 & 25.5 & $\mathrm{C}$ & 1 & 0.17 & 4340 & 1.81 & 240 & 0.88 & 17.2 \\
\hline 149 & $\mathrm{D}$ & 305 & 305 & 30 & 25.5 & $\mathrm{C}$ & 2 & 0.17 & 4340 & 1.81 & 240 & 0.70 & 24.4 \\
\hline 150 & $\mathrm{D}$ & 305 & 305 & 30 & 25.5 & $\mathrm{C}$ & 1 & 0.17 & 4340 & 1.81 & 240 & 0.37 & 19.4 \\
\hline 151 & $\mathrm{D}$ & 305 & 305 & 30 & 25.5 & $\mathrm{C}$ & 2 & 0.17 & 4340 & 1.81 & 240 & 0.28 & 26.0 \\
\hline 152 & $\mathrm{D}$ & 305 & 305 & 30 & 25.5 & $\mathrm{C}$ & 3 & 0.17 & 4340 & 1.81 & 240 & 0.60 & 29.2 \\
\hline 153 & $\mathrm{D}$ & 305 & 305 & 30 & 25.5 & $\mathrm{C}$ & 1 & 0.17 & 4340 & 1.81 & 240 & - & 24.9 \\
\hline 154 & $\mathrm{D}$ & 305 & 305 & 30 & 25.5 & $\mathrm{C}$ & 2 & 0.17 & 4340 & 1.81 & 240 & 0.33 & 26.2 \\
\hline 155 & $\mathrm{D}$ & 305 & 305 & 30 & 25.5 & $\mathrm{C}$ & 3 & 0.17 & 4340 & 1.81 & 240 & 1.24 & 31.1 \\
\hline 156 & $\mathrm{D}$ & 204 & 305 & 20 & 25.5 & $\mathrm{C}$ & 1 & 0.17 & 4340 & 1.81 & 240 & 0.86 & 25.0 \\
\hline 157 & A & 204 & 305 & 20 & 25.5 & $\mathrm{C}$ & 2 & 0.17 & 4340 & 1.81 & 240 & 0.62 & 31.4 \\
\hline 158 & $\mathrm{D}$ & 204 & 305 & 20 & 25.5 & $\mathrm{C}$ & 1 & 0.17 & 4340 & 1.81 & 240 & - & 29.7 \\
\hline 159 & A & 204 & 305 & 20 & 25.5 & $\mathrm{C}$ & 2 & 0.17 & 4340 & 1.81 & 240 & - & 35.3 \\
\hline 160 & $\mathrm{D}$ & 204 & 305 & 20 & 25.5 & $\mathrm{C}$ & 1 & 0.17 & 4340 & 1.81 & 240 & - & 26.9 \\
\hline 161 & A & 204 & 305 & 20 & 25.5 & $\mathrm{C}$ & 2 & 0.17 & 4340 & 1.81 & 240 & 1.42 & 36.1 \\
\hline \multicolumn{14}{|c|}{ Shehata et al. (2002) } \\
\hline 162 & $\mathrm{D}$ & 150 & 150 & 10 & 23.7 & $\mathrm{C}$ & 1 & 0.17 & 3550 & 1.50 & 235 & - & 27.4 \\
\hline 163 & $\mathrm{D}$ & 150 & 150 & 10 & 23.7 & $\mathrm{C}$ & 2 & 0.17 & 3550 & 1.50 & 235 & - & 36.5 \\
\hline 164 & $\mathrm{D}$ & 150 & 150 & 10 & 29.5 & $\mathrm{C}$ & 1 & 0.17 & 3550 & 1.50 & 235 & - & 40.4 \\
\hline 165 & D & 150 & 150 & 10 & 29.5 & $\mathrm{C}$ & 2 & 0.17 & 3550 & 1.50 & 235 & - & 43.7 \\
\hline \multicolumn{14}{|c|}{ Ilki and Kumbasar (2003) } \\
\hline 166 & $\mathrm{D}$ & 250 & 250 & 40 & 32.8 & $\mathrm{C}$ & 1 & 0.17 & 3430 & 1.50 & 230 & - & 32.7 \\
\hline 167 & $\mathrm{D}$ & 250 & 250 & 40 & 32.8 & $\mathrm{C}$ & 1 & 0.17 & 3430 & 1.50 & 230 & - & 32.3 \\
\hline 168 & $\mathrm{~A}$ & 250 & 250 & 40 & 32.8 & $\mathrm{C}$ & 3 & 0.17 & 3430 & 1.50 & 230 & - & 41.4 \\
\hline 169 & $\mathrm{~A}$ & 250 & 250 & 40 & 32.8 & $\mathrm{C}$ & 3 & 0.17 & 3430 & 1.50 & 230 & - & 40.6 \\
\hline 170 & $\mathrm{~A}$ & 250 & 250 & 40 & 32.8 & $\mathrm{C}$ & 5 & 0.17 & 3430 & 1.50 & 230 & - & 56.7 \\
\hline 171 & $\mathrm{~A}$ & 250 & 250 & 40 & 32.8 & $\mathrm{C}$ & 5 & 0.17 & 3430 & 1.50 & 230 & - & 53.6 \\
\hline \multicolumn{14}{|c|}{ Al-salloum (2007) } \\
\hline 172 & $\mathrm{D}$ & 150 & 150 & 5 & 28.7 & $\mathrm{C}$ & 1 & 1.20 & 935 & 1.25 & 75 & - & 41.2 \\
\hline 173 & $\mathrm{D}$ & 150 & 150 & 5 & 30.9 & $\mathrm{C}$ & 1 & 1.20 & 935 & 1.25 & 75 & - & 42.5 \\
\hline 174 & $\mathrm{~A}$ & 150 & 150 & 25 & 31.8 & $\mathrm{C}$ & 1 & 1.20 & 935 & 1.25 & 75 & - & 48.3 \\
\hline 175 & $\mathrm{~A}$ & 150 & 150 & 25 & 28.5 & $\mathrm{C}$ & 1 & 1.20 & 935 & 1.25 & 75 & - & 45.6 \\
\hline 176 & A & 150 & 150 & 38 & 27.7 & $\mathrm{C}$ & 1 & 1.20 & 935 & 1.25 & 75 & - & 57.0 \\
\hline 177 & $\mathrm{~A}$ & 150 & 150 & 38 & 30.3 & $\mathrm{C}$ & 1 & 1.20 & 935 & 1.25 & 75 & - & 55.0 \\
\hline 178 & $\mathrm{~A}$ & 150 & 150 & 50 & 26.7 & $\mathrm{C}$ & 1 & 1.20 & 935 & 1.25 & 75 & - & 61.7 \\
\hline 179 & A & 150 & 150 & 50 & 28.3 & $\mathrm{C}$ & 1 & 1.20 & 935 & 1.25 & 75 & - & 63.7 \\
\hline
\end{tabular}


Table 2. Test results of FRP confined rectangular specimens (Cont.)

\begin{tabular}{|c|c|c|c|c|c|c|c|c|c|c|c|c|c|}
\hline \multirow[b]{2}{*}{ No. } & \multirow[b]{2}{*}{ Note $^{1}$} & \multicolumn{3}{|c|}{ Specimens } & \multicolumn{4}{|c|}{ Concrete } & \multicolumn{5}{|l|}{ FRP } \\
\hline & & $\begin{array}{c}b \\
\mathrm{~mm}\end{array}$ & $\begin{array}{c}h \\
\mathrm{~mm}\end{array}$ & $\begin{array}{c}r \\
\mathrm{~mm} \\
\end{array}$ & $\begin{array}{l}f_{c o}^{\prime} \\
\mathrm{MPa}\end{array}$ & Type $^{2}$ & $\begin{array}{l}\text { No. of } \\
\text { layers }\end{array}$ & $\begin{array}{c}t \\
\mathrm{~mm}\end{array}$ & $\begin{array}{c}f_{f} \\
\mathrm{MPa}\end{array}$ & $\begin{array}{l}\varepsilon_{f u} \\
\%\end{array}$ & $\begin{array}{c}E_{f} \\
\mathrm{GPa}\end{array}$ & $\begin{array}{l}\varepsilon_{f e} \\
\%\end{array}$ & $\begin{array}{l}f^{\prime}{ }_{c c} \\
\mathrm{MPa}\end{array}$ \\
\hline \multicolumn{14}{|c|}{ Tao et al. (2008) } \\
\hline 180 & $\mathrm{~A}$ & 150 & 150 & 20 & 22.0 & $\mathrm{C}$ & 1 & 0.17 & 4470 & 1.87 & 239 & - & 33.5 \\
\hline 181 & $\mathrm{~A}$ & 150 & 150 & 20 & 22.0 & $\mathrm{C}$ & 2 & 0.17 & 4470 & 1.87 & 239 & - & 49.6 \\
\hline 182 & A & 150 & 150 & 20 & 19.5 & $\mathrm{C}$ & 2 & 0.17 & 4470 & 1.87 & 239 & - & 47.2 \\
\hline 183 & $\mathrm{~A}$ & 150 & 150 & 35 & 22.0 & $\mathrm{C}$ & 2 & 0.17 & 4470 & 1.87 & 239 & - & 64.8 \\
\hline 184 & $\mathrm{~A}$ & 150 & 150 & 35 & 19.5 & $\mathrm{C}$ & 2 & 0.17 & 4470 & 1.87 & 239 & - & 58.7 \\
\hline 185 & $\mathrm{~A}$ & 150 & 150 & 50 & 22.0 & $\mathrm{C}$ & 2 & 0.17 & 4470 & 1.87 & 239 & - & 76.6 \\
\hline 186 & $\mathrm{~A}$ & 150 & 150 & 50 & 19.5 & $\mathrm{C}$ & 2 & 0.17 & 4470 & 1.87 & 239 & - & 63.6 \\
\hline 187 & $\mathrm{D}$ & 150 & 150 & 20 & 49.5 & $\mathrm{C}$ & 1 & 0.17 & 4470 & 1.87 & 239 & - & 54.2 \\
\hline 188 & A & 150 & 150 & 20 & 49.5 & $\mathrm{C}$ & 2 & 0.17 & 4470 & 1.87 & 239 & - & 61.4 \\
\hline 189 & $\mathrm{~A}$ & 150 & 150 & 35 & 49.5 & $\mathrm{C}$ & 2 & 0.17 & 4470 & 1.87 & 239 & - & 84.9 \\
\hline 190 & A & 150 & 150 & 50 & 49.5 & $\mathrm{C}$ & 2 & 0.17 & 4470 & 1.87 & 239 & - & 86.1 \\
\hline
\end{tabular}




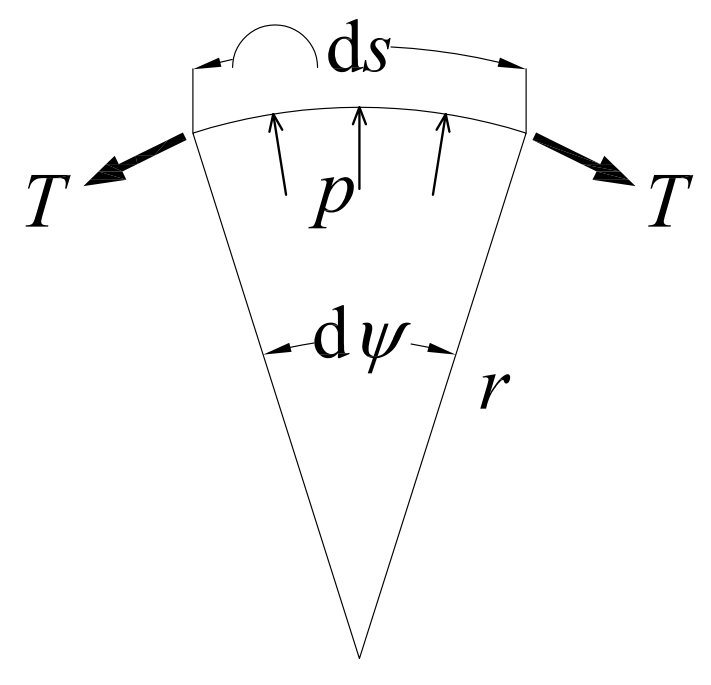

(a)

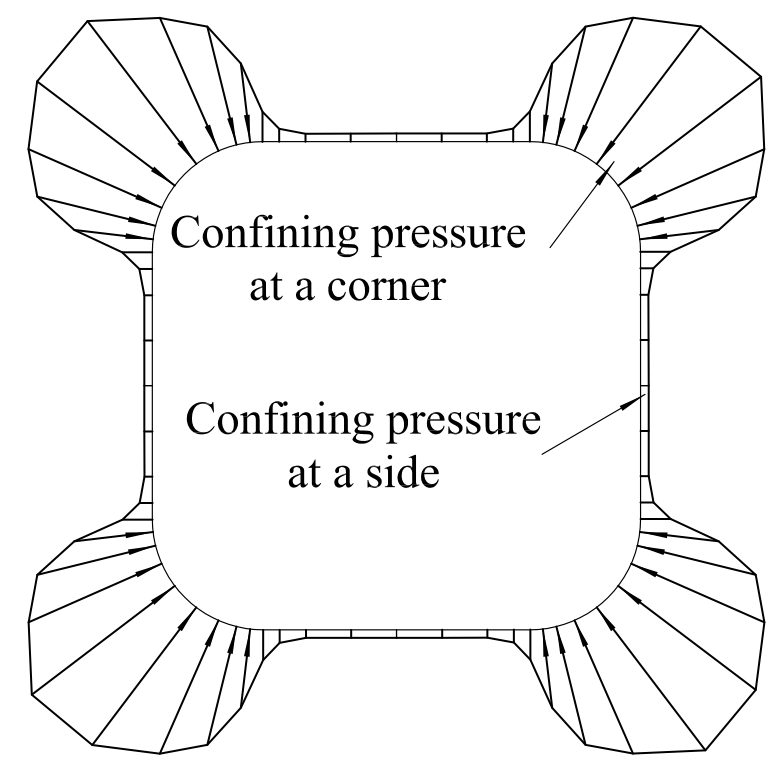

(b)

Accepted Manuscript Not Copyedited 

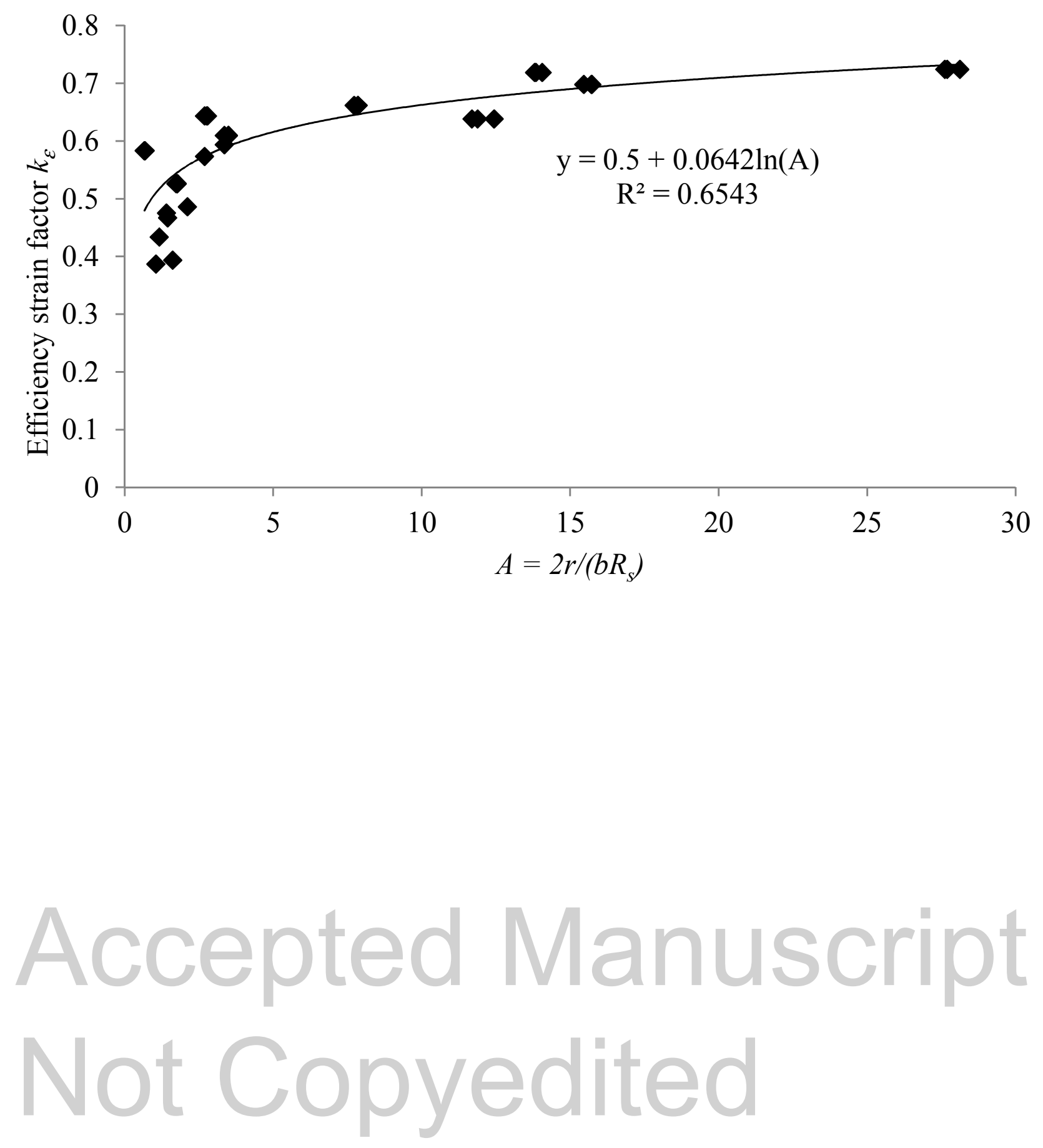


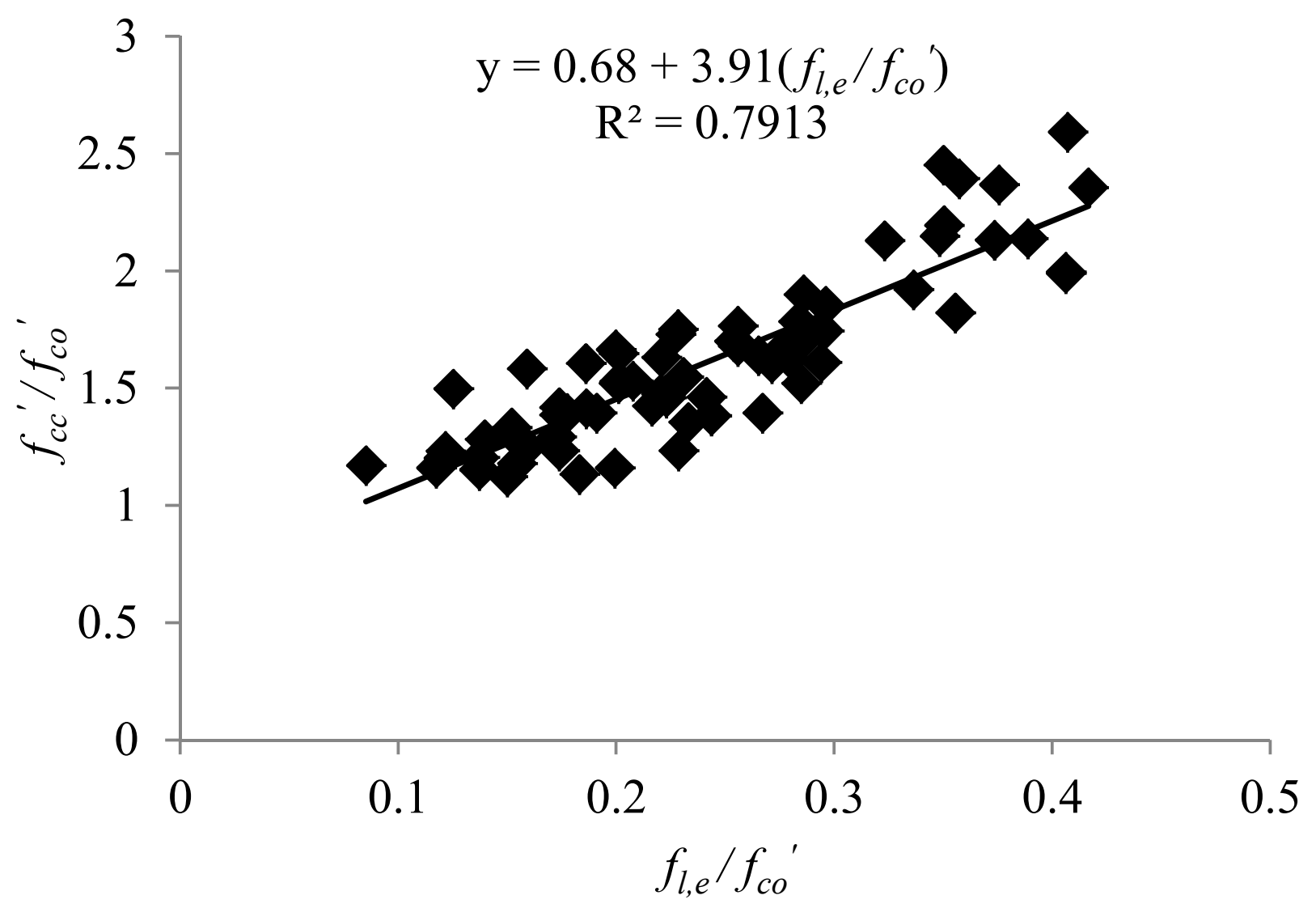

Accepted Manuscript Not Copyedited 

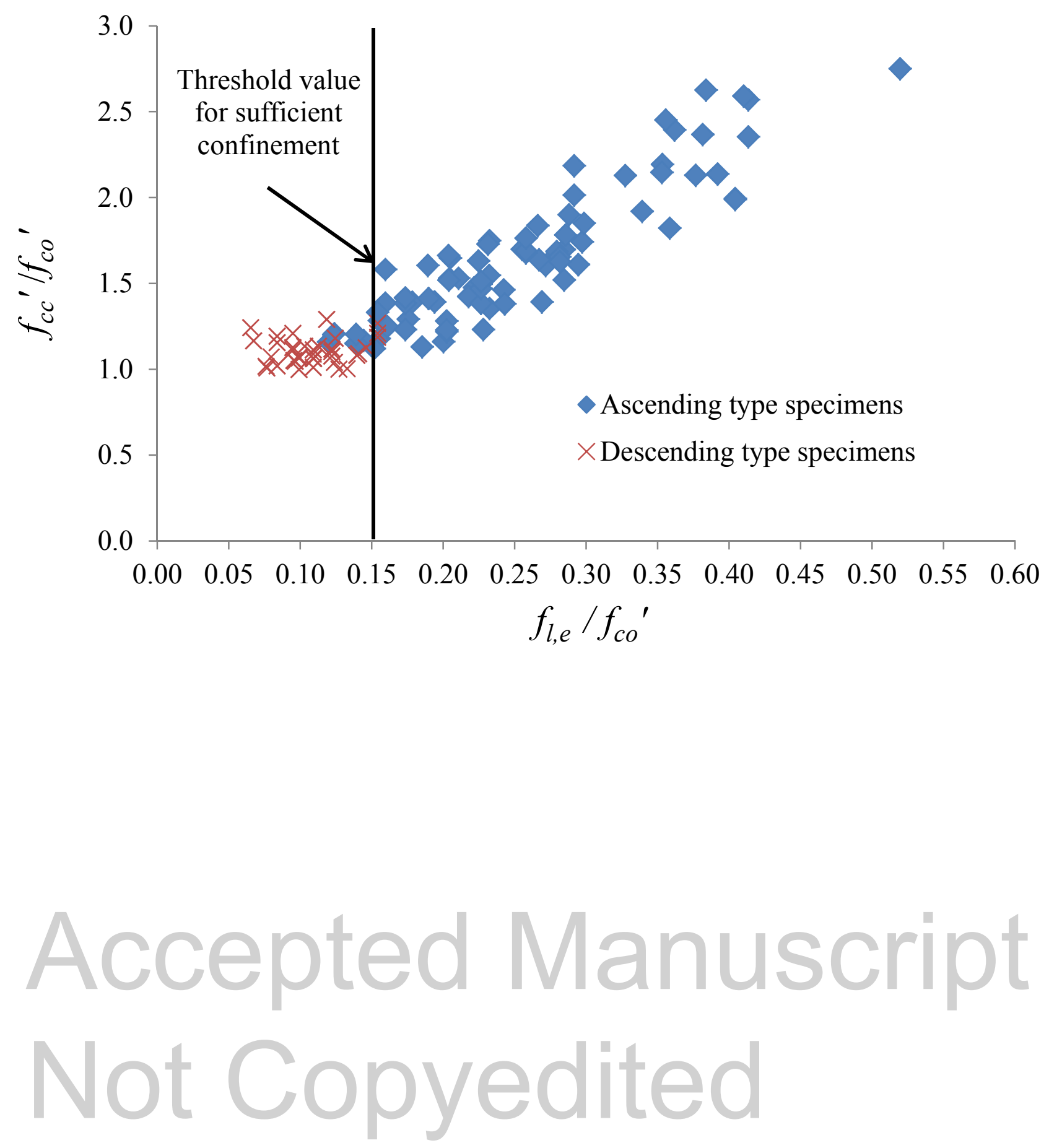

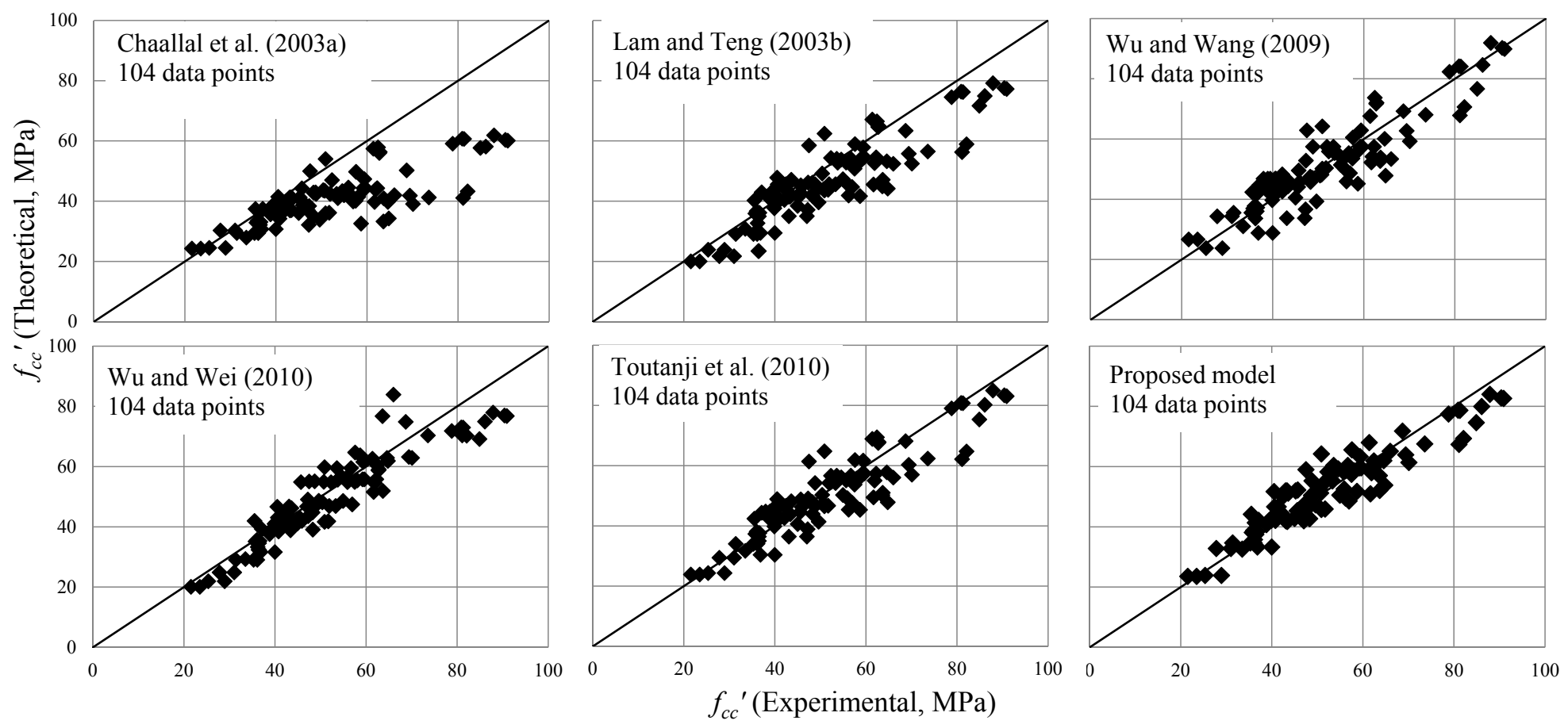


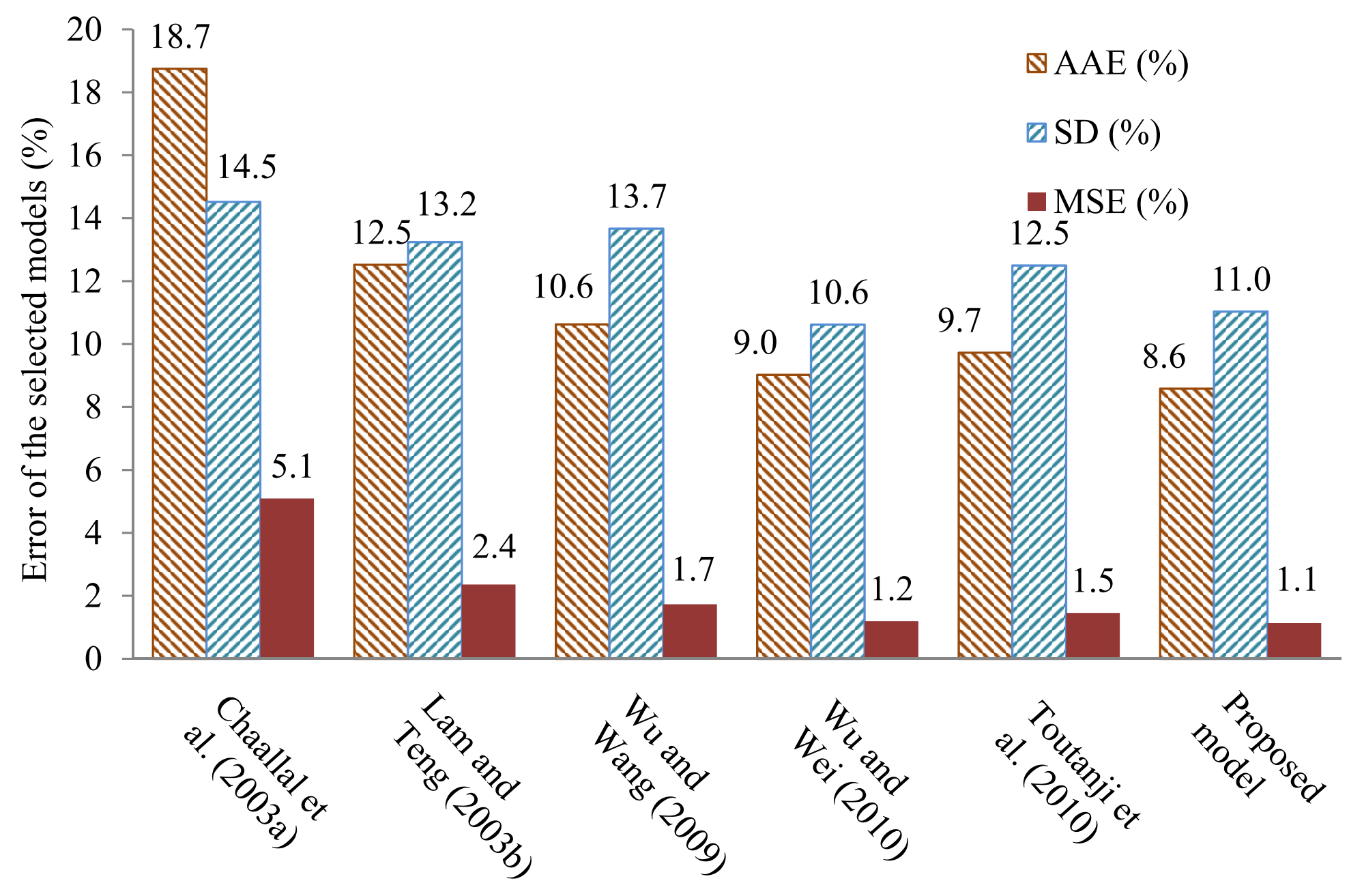




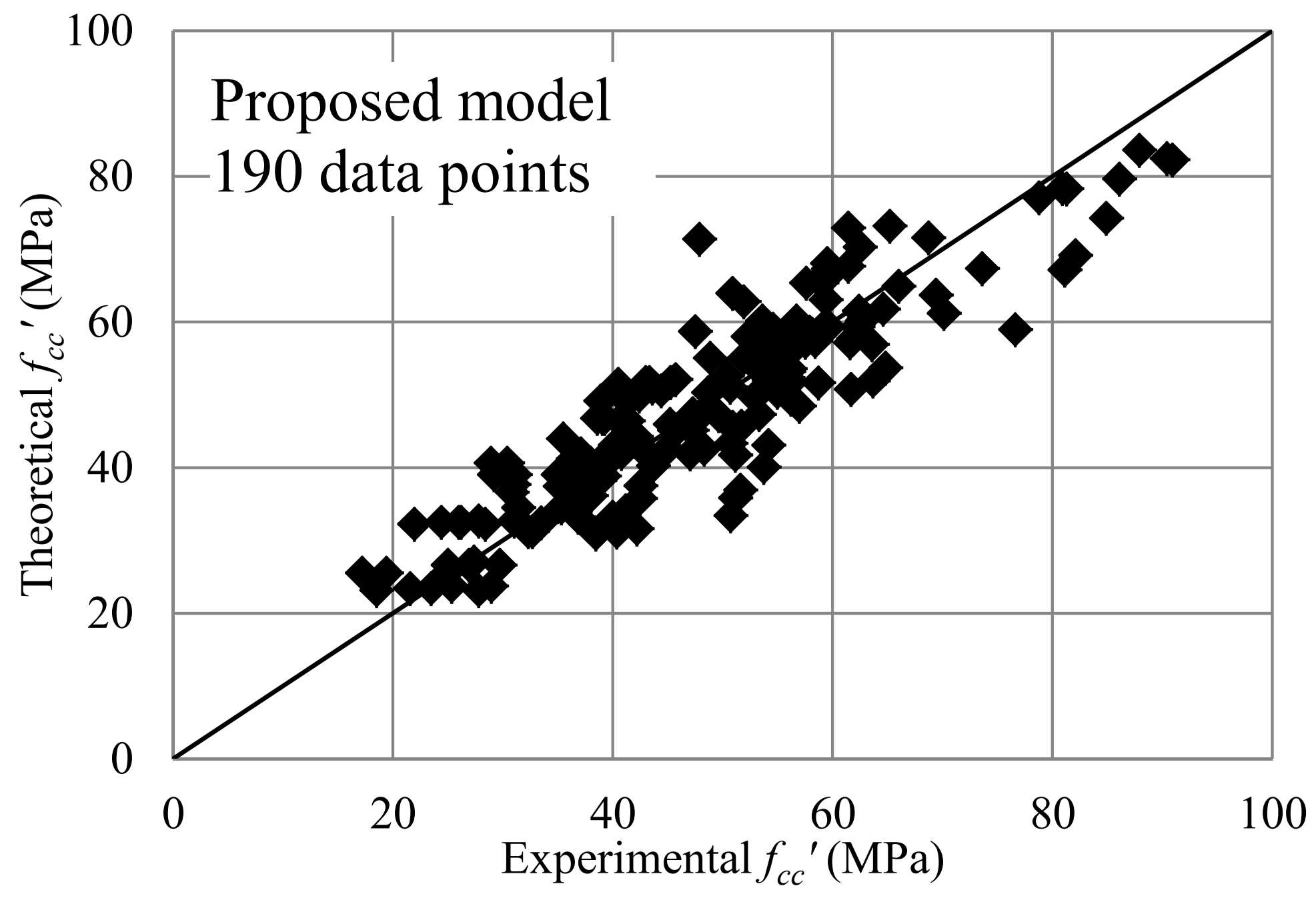

